University of Nebraska - Lincoln

DigitalCommons@University of Nebraska - Lincoln

\title{
Regional scale patterns of fine root lifespan and turnover under current and future climate
}

\author{
M. Luke Mccormack \\ Pennsylvania State University, mltmcc@gmail.com \\ David M. Eissenstat \\ Pennsylvania State University, dme9@psu.edu \\ Anantha M. Prasad \\ USDA Forest Service \\ Erica A. H. Smithwick \\ Pennsylvania State University, smithwick@psu.edu
}

Follow this and additional works at: https://digitalcommons.unl.edu/usdaarsfacpub

Mccormack, M. Luke; Eissenstat, David M.; Prasad, Anantha M.; and Smithwick, Erica A. H., "Regional scale patterns of fine root lifespan and turnover under current and future climate" (2013). Publications from USDA-ARS / UNL Faculty. 1286.

https://digitalcommons.unl.edu/usdaarsfacpub/1286

This Article is brought to you for free and open access by the U.S. Department of Agriculture: Agricultural Research Service, Lincoln, Nebraska at DigitalCommons@University of Nebraska - Lincoln. It has been accepted for inclusion in Publications from USDA-ARS / UNL Faculty by an authorized administrator of DigitalCommons@University of Nebraska - Lincoln. 


\title{
Regional scale patterns of fine root lifespan and turnover under current and future climate
}

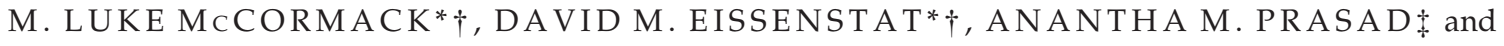 \\ ERICA A. H. SMITHWICK†§ \\ *Department of Ecosystem Science and Management, The Pennsylvania State University, 109 Tyson Building, University Park, \\ PA 16802, USA, †Intercollege Graduate Degree Program in Ecology, The Pennsylvania State University, 109 Tyson Building, \\ University Park, PA 16802, USA, \$Northeastern Research Station, USDA Forest Service, 359 Main Road, Delaware, OH 43015, \\ USA, §Department of Geography, The Pennsylvania State University, 302 Walker Building, University Park, PA 16802, USA
}

\begin{abstract}
Fine root dynamics control a dominant flux of carbon from plants and into soils and mediate potential uptake and cycling of nutrients and water in terrestrial ecosystems. Understanding of these patterns is needed to accurately describe critical processes like productivity and carbon storage from ecosystem to global scales. However, limited observations of root dynamics make it difficult to define and predict patterns of root dynamics across broad spatial scales. Here, we combine species-specific estimates of fine root dynamics with a model that predicts current distribution and future suitable habitat of temperate tree species across the eastern United States (US). Estimates of fine root lifespan and turnover are based on empirical observations and relationships with fine root and whole-plant traits and apply explicitly to the fine root pool that is relatively short-lived and most active in nutrient and water uptake. Results from the combined model identified patterns of faster root turnover rates in the North Central US and slower turnover rates in the Southeastern US. Portions of Minnesota, Ohio, and Pennsylvania were also predicted to experience $>10 \%$ increases in root turnover rates given potential shifts in tree species composition under future climate scenarios while root turnover rates in other portions of the eastern US were predicted to decrease. Despite potential regional changes, the average estimates of root lifespan and turnover for the entire study area remained relatively stable between the current and future climate scenarios. Our combined model provides the first empirically based, spatially explicit, and spatially extensive estimates of fine root lifespan and turnover and is a potentially powerful tool allowing researchers to identify reasonable approximations of forest fine root turnover in areas where no direct observations are available. Future efforts should focus on reducing uncertainty in estimates of root dynamics by better understanding how climate and soil factors drive variability in root dynamics of different species.
\end{abstract}

Keywords: belowground, carbon allocation, DISTRIB, dynamic global vegetation model (DGVM), ecological modeling, minirhizotron, tree distribution

Received 17 November 2012 and accepted 8 January 2013

\section{Introduction}

Temperate forests play a major role in the global carbon (C) cycle as well as in regional nutrient and water cycles (Vitousek, 1982; Dixon et al., 1994; Schimel, 1995; Fan et al., 1998; Goodale et al., 2002; Jackson et al., 2005; Pan et al., 2011). In these systems, fine roots are responsible for nutrient and water uptake into plants and account for between $10 \%$ and $60 \%$ of net primary productivity (Grier et al., 1981; Jackson et al., 1997).

Correspondence: Present address: M. Luke McCormack, Key Laboratory of Ecosystem Network Observation and Modeling, Synthesis Research Center of Chinese Ecosystem Research Network, Institute of Geographic Sciences and Natural Resources Research, Chinese Academy of Sciences, Beijing, 100101, China, tel. +8610 64888153, fax +8610 64888153, e-mail:

mltmcc@gmail.com
Furthermore, development of potentially long-term C storage pools in the soil organic matter of mineral soils may be driven largely by the turnover of fine roots (Richter et al., 1999; Rasse et al., 2005; Tefs \& Gleixner, 2012). Despite the recognized importance of fine root dynamics, we have little understanding of broad spatial patterning of these processes.

Terrestrial biogeochemistry models and dynamic global vegetation models (DGVMs) are increasingly limited by incomplete descriptions of critical belowground processes (Jackson et al., 2000; Tatarinov \& Cienciala, 2006; Iversen, 2010). This is due partly to a lack of available data describing these processes consistently across sites and at appropriate spatial scales (Ostle et al., 2009). Due to the difficulty associated with measuring root dynamics in the field, most model applications are forced to either simplify global patters to one or a few 
estimates (e.g., Sitch et al., 2003), adjust rough estimates through model optimization procedures (e.g., Medvigy et al., 2009), or generate estimates for target species based on estimates reported in other field studies (e.g., Smithwick et al., 2009). This last option is arguably most ideal, but only when relevant estimates are available for the same or closely related species and sites. However, estimates of fine root lifespan and fine root turnover are not available for many species or regions, leaving researchers with no clear answer for how best to estimate root dynamics for their site or species.

Despite the difficulty and uncertainty concerning estimates of root dynamics, the need for more accurate parameterization of these variables in models is striking. For example, working with BIOME-BGC, Tatarinov \& Cienciala (2006) found that decoupling estimates of fine root turnover from that of leaf turnover had strong effects on estimates of standing root biomass and litterfall, buildup of the soil organic matter pool, and on total system production and aboveground biomass. Similarly, a model intercomparison where fine root turnover rates were adjusted within the range of estimates currently used in models, found strong effects of these adjustments on total system C (live and dead above- and belowground biomass, litter, and soil organic matter) (McCormack, 2012). Here, changes of $10-30 \%$ in total system $C$ were observed when model structures included direct coupling of total plant or system productivity to belowground resource availability as mediated by root uptake. The importance of including and accurately describing root dynamics is further echoed in several other recent studies that highlight root production, respiration, exudation, and turnover as key areas of uncertainty in a wide range of model applications (Kucharik et al., 2006; Ciais et al., 2008; Malhi et al., 2011; Kim et al., 2012).

In this study, we establish an empirical basis for describing fine root lifespan and turnover at broad spatial scales and address three specific objectives. First, we identify patterns of faster and slower fine root lifespan and turnover across temperate forests of the eastern United States (US). Second, we identify how these patterns might shift given potential shifts in the distributions of suitable habitat for different tree species under future climate scenarios. Our third objective, parallel to objectives one and two, was to provide a tool from which modelers can obtain first approximations of root dynamics in forests across the eastern US when little or no direct empirical observations are available. To address these objectives, we combined species-specific estimates of fine root lifespan with an existing model of tree species distribution in the eastern US. The model of tree species distribution and future suitable habitat, DISTRIB, was developed by the
US Forest Service (Prasad et al., 2006; Iverson et al., 2008) and predicts the distribution and suitable habitat for 134 tree species based on characteristics of soil, land use, topography, landscape pattern, and climate. Our species-specific estimates of fine root lifespan are derived from a review of published literature from which we derived species-specific estimates of fine root lifespan and turnover for 95 species using a combination of direct observations of fine root dynamics coupled with known trait relationships between root lifespan and more easily measured root- and wholeplants traits. In this analysis, our estimates focus on the shorter lived, more ephemeral fine root pool within the more broadly defined class of fine roots as this is the relevant pool for resource uptake and is purported to be described under standard fine root classifications.

\section{Methods}

\section{DISTRIB model}

The DISTRIB model has been previously described (Prasad et al., 2006; Iverson et al., 2008) and is available for browsing online (Prasad et al., 2007). Briefly, the model predicts the distribution and importance value (IV) for 134 temperate tree species based on climate, topography, soil class, soil properties, and land use. The model was built using and tested against Forest Inventory Analysis data (www.fia.fs.fed.us). The DISTRIB model yields predicted IVs for each species separately on a 20 by $20 \mathrm{~km}$ grid cell for all land area east of the 100 th meridian in the US. During our analysis, we used predicted current tree distributions and predictions of future suitable habitat under three climate scenarios; current, GCM3Lo and GCM3Hi. The Lo and Hi scenarios are based on B1 and A1FI $\mathrm{CO}_{2}$ emissions scenarios, respectively. The current climate scenario is based on the period from 1960 to 1990 and the future climate scenarios are based on an average of three separate climate models (Hadley CM3 GCM model, Geophysical Fluid Dynamics Laboratory, Parallel Climate Model) under the Lo and $\mathrm{Hi} \mathrm{CO}$ emissions scenarios for the period 20702100. These yield estimates of precipitation and temperature across the study area which contributes to patterns of potential species distributions. The current predicted and potential future tree distributions were then combined with species-specific estimates of fine root lifespan and turnover.

\section{Estimates of fine root lifespan and turnover}

Estimates of fine root lifespan were determined for 95 of the most common temperate tree species in the eastern US. Whenever possible, these estimates were derived from published values of fine root lifespan or fine root turnover obtained through direct observations of fine roots through time (e.g., rhizotrons and minirhizotrons). This was possible for 19 of the 95 total species. For a further 64 species, estimates of root lifespan and turnover were not directly available, but were available for congeneric species. Here, we used 
an estimate of lifespan from the congener and then adjusted the lifespan higher or lower based on plants traits identified in McCormack et al. (2012). Specifically, species with faster growth rates or in some cases, lower wood densities were assigned a shorter root lifespan than the original congeneric species while species with slower growth rates (higher wood density) were assigned longer median root lifespans. Adjustments were relatively conservative and typically ranged between $5 \%$ and $15 \%$ increases or decreases from original observations from original congeneric comparisons. Relative estimates of faster and slower growth were obtained primarily from the USDA plants database (www.plants.usda.gov) as well as Burns \& Honkala (1990a,b). Estimates of wood density were obtained from the Global Wood Density Database (Zanne et al., 2009). A final 12 species that represented particularly important and common species in forests of the eastern US were included despite a lack of available species- or genus-specific root lifespan or root turnover data. Here, estimates of root lifespan were based on plant and root traits (whole plant growth rate, wood density, and fine root diameter; McCormack et al., 2012). Estimates and justification for all 95 species are given in Table S1.

Species-specific estimates of fine root turnover were first calculated using a linear equation relating median lifespan of a given species to an estimate of fine root turnover reported in McCormack (2012).

$$
\mathrm{T}_{R_{i}}=-0.0043 * L_{R_{i}}+2.363
$$

where $\mathrm{T}_{R i}$ fine root turnover rate $\left(\mathrm{yr}^{-1}\right)$ and $\mathrm{L}_{R_{i}}$ is the median fine root lifespan (days) of a given species. However, Eqn (1) was developed using species whose lifespan ranged from 95 to 336 days and did not include any examples with lifespans over 1 year. Following Eqn (1) for longer lived roots results in unreasonably low to negative estimates of turnover roots. As a result, for species with median lifespans greater than 1 year root turnover was calculated using Eqn (1) and was also calculated as the inverse of lifespan:

$$
\mathrm{T}_{\text {Inv }}=\frac{365 \text { (days) }}{L_{R_{i}}}
$$

where $\mathrm{T}_{I n v_{i}}$ is the fine root turnover rate calculated using the inverse method (Majdi et al., 2005; McCormack, 2012). This typically results in a faster estimated turnover rate. The final turnover rate used is based on both $\mathrm{T}_{R i}$ and $\mathrm{T}_{I n v_{i}}$.

\section{Combining DISTRIB with estimates of fine root lifespan and turnover}

Species-specific estimates of fine root lifespan and turnover were combined with spatially explicit predictions of species distributions and local IVs. This was done using a weighted average approach based on the dominance (i.e., IV) and estimated root turnover or root lifespan for each given species. For example, a simple forest consisting of two species of equal dominance (IV $=50$ for both species), each with median fine root lifespans of 100 and 200 days, respectively, would have an estimated median fine root lifespan of 150 days for the forest stand. This was done using 95 tree species according to the following:

$$
L_{F S}=\Sigma\left(\frac{I V_{i} * L_{R_{i}}}{\Sigma I V_{i}}\right)
$$

or similarly

$$
\mathrm{T}_{F S}=\Sigma\left(\frac{I V_{i} * \mathrm{~T}_{R_{i}}}{\Sigma I V_{i}}\right)
$$

where is $L_{F S}$ is the estimated median fine root lifespan (days) and $\mathrm{T}_{F S}$ is the estimated fine root turnover rate $\left(\mathrm{yr}^{-1}\right)$ for the whole forest stand which are based on species-specific median root lifespan $\left(L_{R_{i}}\right)$, turnover rate $\left(\mathrm{T}_{R_{i}}\right)$, and importance value $\left(\mathrm{IV}_{i}\right)$. These are summed for all species and then repeated for each 20 by $20 \mathrm{~km}$ grid cell across the landscape.

\section{Model uncertainty}

Uncertainty in the model is expressed using three main components; the total species-specific IV covered, a confidence estimate, and an uncertainty score. Each component is calculated for each grid cell and is defined as follows. First, the total IV covered was defined as

$$
I V_{c o v}=\Sigma I V_{i}
$$

where $I V_{c o v}$ is the sum of each species-specific importance value $\left(I V_{i}\right)$ for a given grid cell. $I V_{\text {cov }}$ theoretically ranges from 0 to 100 where 0 means that of the tree species represented in the model, none are present in the given forest stand and a value of 100 means that all trees within a given forest stand are represented in the model. However, because DISTRIB predicts IVs for each species separately, the total IV covered by adding each species-specific IV does not always equal 100 and occasionally is much higher $(>110)$. However, the fraction of estimates for $I V_{c o v}$ that are substantially larger than 100 is less than five percent and does not impact interpretations of the model output.

The model confidence estimate is made up of a reliability score for how well DISTRIB predicts the distribution and IV for a given species together with a measure of confidence for the species-specific estimates of fine root lifespan and turnover. These are combined using the following:

$$
M C=\Sigma\left(\frac{I V_{i} * C D_{i} * C R_{i}}{\Sigma I V_{i}}\right)
$$

where $C D_{i}$ is the reliability score from DISTRIB and $C R_{i}$ is the measure of confidence for the species-specific estimate of root lifespan and turnover (confidence between estimates for lifespan and turnover was the same). Species-specific assignments for $C D_{i}$ are based on assessment of model reliability by Iverson et al. (2008) in which species were split into three classes: high, medium, and low reliability. These classes were used and scored as $1=$ high and $3=$ low reliability. Across the 95 species 49,34 , and 14 species had scores $C D$ of 1,2 , and 3 , respectively. Assessment of fine root lifespan and turnover was similarly scored as $1=$ high and $3=$ low reliability. Here, species were assigned a score of one if there were one or more 
relevant studies that had published estimates of root lifespan and or turnover. Species with no direct, relevant assessment of root dynamics available, but where estimates for a congeneric species had been published were assigned a score of two. Congeneric estimates of root dynamics provided a first approximation that could then be adjusted based on wholeplant traits as described above. Finally, species whose root lifespan and turnover estimates were determined solely based on their root and whole-plant traits were assigned a score of three. Across the 95 species 19, 64, and 12 species had $C R_{i}$ scores of one, two, and three, respectively. Values of $C D_{i}$ and $C R_{i}$ for each species are listed in Table S1.

A single integrative measure of model uncertainty was calculated that combined both $I V_{c o v}$ and $M C$. The uncertainty score ranges from 0 to 100 and is a relative measure of how well the model may be describing forest fine root lifespan and turnover for a given grid cell according to the following:

$$
\text { Uncertainty Score }=\left(\frac{50}{M C}+\frac{I V_{c o v}}{2}\right)
$$

Derivation of the uncertainty score is given in Supplemental Text 1 .

\section{Model assumptions}

There are important assumptions and simplifications built into the model stemming from the DISTRIB model, the speciesspecific estimates of root lifespan and turnover, and the methodology for combining the two. First, many important assumptions and limitations of the DISTRIB model are detailed in previously published studies (Iverson et al., 2008, 2011). However, there are a few particularly important notes that should be made regarding the predicted species distributions from DISTRIB. DISTRIB generally reproduces current patterns of most species distributions well. However, predictions of future distributions do not account for human-induced land-use change, changes in fire regimes, species migration rates, atmospheric nitrogen deposition, pest outbreaks, and the likelihood that populations of trees that established in an area may remain for as much as several hundred years even if future climate is not favorable for seedling recruitment. Therefore, DISTRIB is primarily describing potential future distributions; i.e., what geographical areas are likely to serve as suitable habitat for a given species. This distinction should be considered when interpreting results from the combined DISTRIB and root dynamics model.

Species-specific data describing fine root dynamics are extremely limited. Here, we compiled species-specific and genus-specific data and identified whole-plant traits that relate to root dynamics to estimate root lifespan and turnover for 95 common temperate tree species in the eastern US. There are known limitations and assumptions that stem from using estimates of root dynamics derived from different studies that use somewhat variable methodology. In addition, we also make the simplifying assumption that a single estimate for a species will sufficiently represent that species across the geographic range in which that species is found. This discounts the potential for climate and edaphic factors to mediate root lifespan and turnover (Burton et al., 2000).

Finally, central to linking species-specific estimates of fine root dynamics with IVs from DISTRIB is the simplifying assumption that rooting densities are equal between tree species with equal IV. This is likely not true for many species. However, in the absence of sufficient empirical evidence to make assertions regarding rooting densities of different species in the context of a mixed forest we use this unbiased assumption to help build broad approximations of forest fine root lifespan and turnover.

\section{Mapping of model results}

Results from the combined model of tree species distributions and fine root dynamics were mapped using ArcMap v10.0. Maps were produced two ways. First, results were displayed as direct output from the model across the landscape. However, in some situations this method may incorrectly lead to interpretations that forests cover nearly all of the eastern US as DISTRIB identifies and predicts potential tree species habitats across nearly all 20 by $20 \mathrm{~km}$ grid cells. To compensate for this, we reproduced each map and overlaid the model output with data from the National Land Cover Database 2001 (NLCD) for percent tree canopy cover at a spatial resolution of $30 \mathrm{~m}$ (www.mrlc.gov) (Homer et al., 2004). This was done by classifying cells from the NLCD in one of the two categories: forest or nonforest. In areas where tree canopy coverage was $20 \%$ or less, the cells were masked to obscure the model results. This limits model output and interpretation approximately to land areas that currently contain at least a minimum of $20 \%$ tree cover. Applying this mask to the maps of potential future patterns of root dynamics discounts the possibility for substantial land-use change over the next century. While at a local scale, this simplification is faulty, at broader, regional scales it provides a useful approach to focus attention away from heavily agricultural or urban areas or other regions that lack significant tree cover which are not likely captured well in the current model.

\section{Results}

\section{Current patterns of root turnover and lifespan}

In this analysis, we combined species-specific estimates of fine root lifespan and turnover with spatially explicit predictions of current and future potential distributions of temperate tree species across the eastern US. Across the study area, the average turnover rate was $1.27 \mathrm{yr}^{-1}$ and ranged from 0.70 to $1.96 \mathrm{yr}^{-1}$ (Fig. 1). While the full range of turnover rates predicted by the model was relatively large, approximately $95 \%$ of predicted turnover rates were between 1.07 and $1.47 \mathrm{yr}^{-1}$. Areas of fastest root turnover were centered in northern Minnesota and northern Wisconsin while areas with the slowest turnover rates were observed across much of the central portion of the US (South Dakota, Nebraska, 


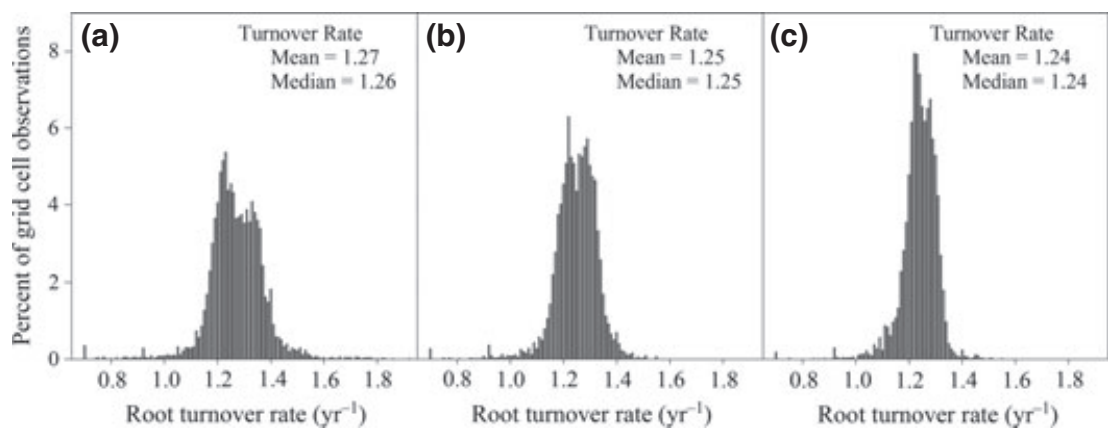

Fig. 1 Distribution of predicted fine root turnover rates observed across the eastern United States under (a) current $(n=9284)$, (b) future low $\mathrm{CO}_{2}$ emissions ( $n=9398$ ) and (c) future high $\mathrm{CO}_{2}$ emissions $(n=9638)$ climate scenarios.
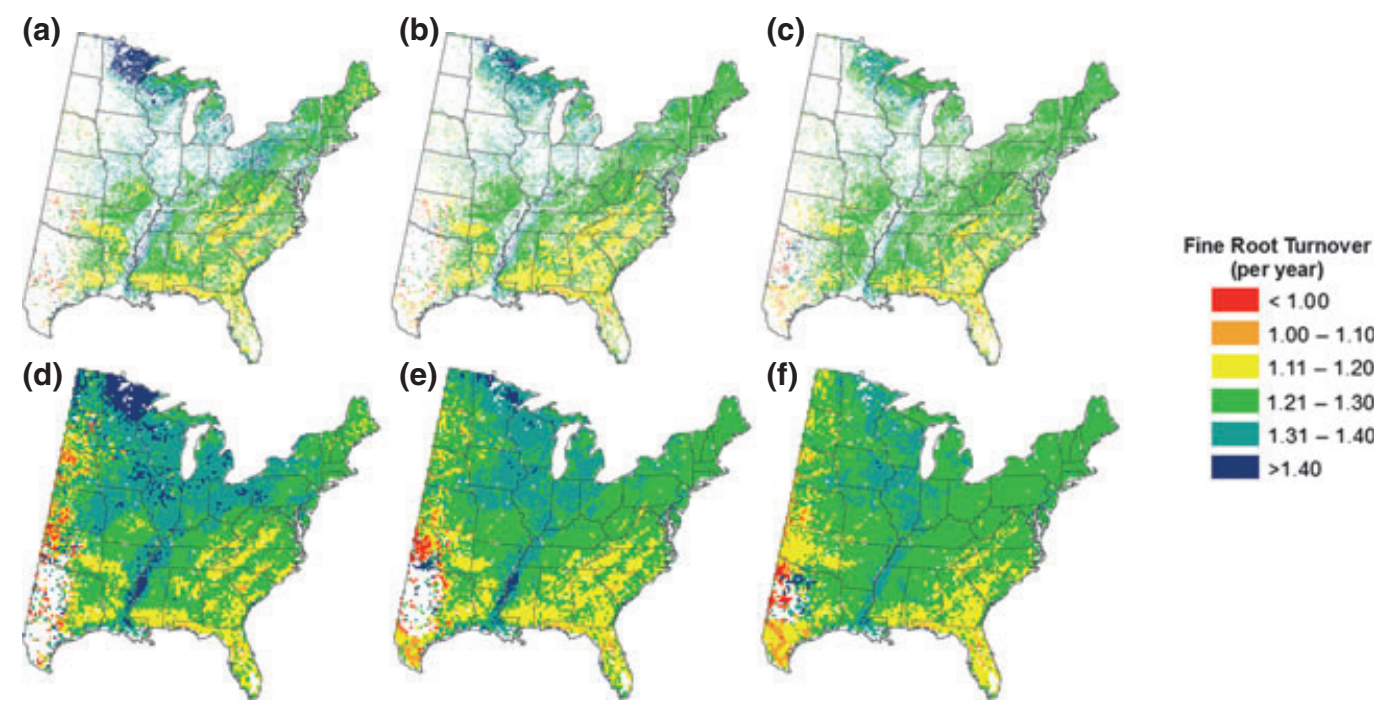

Fig. 2 Forest fine root turnover rates across the eastern United State under current (a and d), future low $\mathrm{CO}_{2}$ emissions (b and e), and future high $\mathrm{CO}_{2}$ emissions climate scenarios (c and f). Panels (a-c) are overlain with NLCD cover data to mask areas with less than $20 \%$ forest canopy cover. Panels $(\mathrm{d}-\mathrm{f})$ do not have the NLCD cover mask.

western Kansas, and western Oklahoma) (Fig. 2a). However, these states do not contain high levels of forest cover (Fig. 2d). Isolated areas of slow root turnover also appear in regions of the southeast US.

Addressing our first objective, we found that distinct patterns of root lifespan and turnover do exist across the eastern US. The observation of broad spatial patterns of root dynamics was not necessarily expected as, with the exception of monoculture timber plantations, most temperate forests contain multiple species of trees expressing a mix of faster and slower root turnover rates. These mixed compositions would, in many cases, result in a more average turnover rate for the whole forest stand (or grid cell). For example, much of the land area in Pennsylvania was estimated to have a fine root turnover rate between the relatively narrow range of $1.1-1.3 \mathrm{yr}^{-1}$ despite the fact that temperate forests across the state can be relatively diverse and contain species common to both the northern and southern portions of the eastern US. Similarly, central to northern Michigan was predicted to have a turnover rate between 1.2 and $1.3 \mathrm{yr}^{-1}$ despite having a large proportion of Populus tremuloides, with much faster root turnover rate, because the influence of $P$. tremuloides is balanced by relatively high proportions of Acer saccharum with a relatively slow root turnover rate. ${ }^{1}$

If the mixed-species composition of most temperate forests usually leads to an average root turnover rate, why then do some mixed temperate forests show distinct patterns of faster and slower root turnover rates? Deviations from the average turnover estimates occur

\footnotetext{
${ }^{1}$ Maps of the current distribution for each species used in this analysis based on FIA data as well as modeled distributions of each species based on DISTRIB can be viewed online (www. nrs.fs.fed.us/atlas/tree).
} 

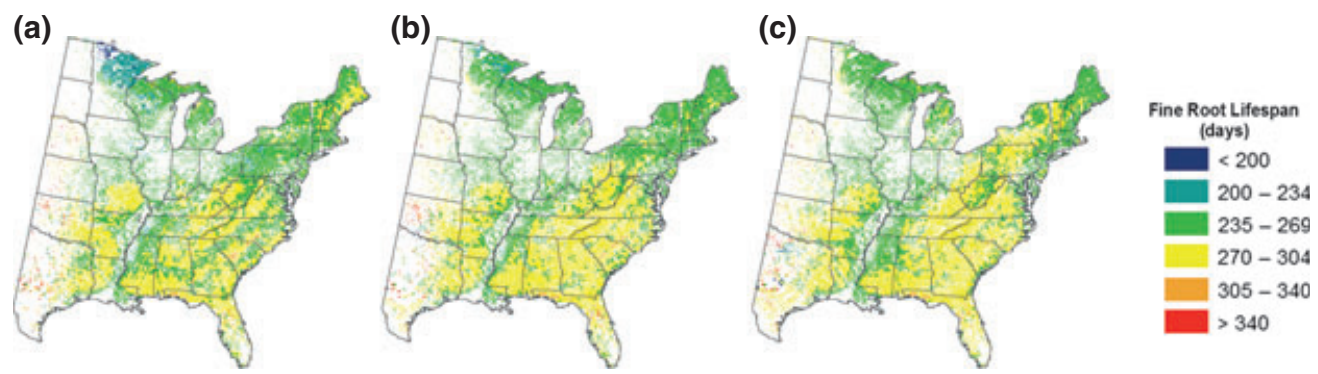

Fig. 3 Forest fine root lifespan across the eastern United State under current (a), future low $\mathrm{CO}_{2}$ emissions (b), and future high $\mathrm{CO}_{2}$ emissions climate scenarios (c).

as some areas can be marked by high abundances of one of a few species with relatively fast or slow turnover rates. This resulted in faster estimated turnover rates in northern Minnesota dominated by Betula papyrifera, P. tremuloides, P. balsamea, and Picea mariana; western Pennsylvania and eastern Ohio with high abundances of Prunus serotina; and the area surrounding the lower Mississippi River (Carya aquatica and Fraxinus pennsylvanica) (Fig. 2). Conversely, the localized points of slow root turnover rate predicted for western Florida, central South Carolina, and southcentral North Carolina correspond to increased dominance of Quercus laevis with slow root turnover rate and corresponding decreases in the otherwise dominant southern species, Liquidambar styraciflua, which has faster root turnover rates.

The predicted patterns and distribution of fine root lifespan followed similar trends as fine root turnover (Fig. 3). The similarity between the different variables is not surprising as fine root turnover rates for many of the species used in the model were generated using fine root lifespan Eqns (1) and (2). Overall, average lifespan predicted across the eastern US was roughly 270 days and ranged from 125 to 450 days (95\% range of 220-335 days).

\section{Shifts in patterns of turnover and lifespan with future climate}

Addressing our second objective, we determined whether there were specific areas within the eastern US that were likely to experience considerable increases or decreases in fine root turnover (and lifespan) based on potential shifts in suitable habitats for different species. Overall, broad patterns of fine root lifespan and turnover were similar between the current climate, future low emissions, and future high emissions scenarios (Figs. 2 and 3). However, we identified four main regions with consistent responses to future climate scenarios (Fig. 4). First, both northern Minnesota and parts of the mid-Atlantic region, especially western Pennsyl- vania and eastern Ohio, were predicted to experience greater than $10 \%$ decreases in root turnover rate. However, the species shifts driving these trends were different in each region. The decrease in Minnesota was driven primarily through the loss of Poplar species with faster root turnover rates like $P$. tremuloides and $P$. balsamea and their replacement by species with slower root turnover like $A$. saccharum. In the midAtlantic region this was due to the loss of $P$. serotina and potential replacement by various oak species. At the same time, areas in the New England region and parts of the southcentral US were predicted to see increasing turnover rates. In the New England region, and Maine in particular, this was due to decreases in $A$. saccharum, Abies balsamea, and Tsuga canadensis, each with estimated turnover rates of $<1.0 \mathrm{yr}^{-1}$. The potential increase in root turnover rate observed in the southcentral US (parts of Louisiana, Arkansas, Texas, and Oklahoma) were more difficult to attribute to specific increases and decreases of certain species and is likely the result of more subtle changes across many species. The model also predicted large increases in turnover and decreases in root longevity in the central portion of the US. However, these again may be unrealistic or irrelevant as there is unlikely to be significant forest cover across these areas.

Overall, the central tendency of fine root turnover, and similarly lifespan, changed little between the current climate and the future climate scenarios. However, the distribution appears to narrow from the current to the future low and future high $\mathrm{CO}_{2}$ emissions scenarios (Fig. 1). Standard deviation decreases from 0.10 in the current climate scenario to 0.08 and 0.07 in the future low and future high $\mathrm{CO}_{2}$ emissions scenarios, respectively. Accordingly, the envelope containing $95 \%$ of observed turnover values narrowed from 1.07 to $1.47 \mathrm{yr}^{-1}$ in the current climate scenario to $1.06-$ $1.34 \mathrm{yr}^{-1}$ in the future high emissions climate scenario. The apparent homogenization of forest fine root turnover rates across the eastern US (Fig. 2) was due to the predicted decreases in many of the common species 


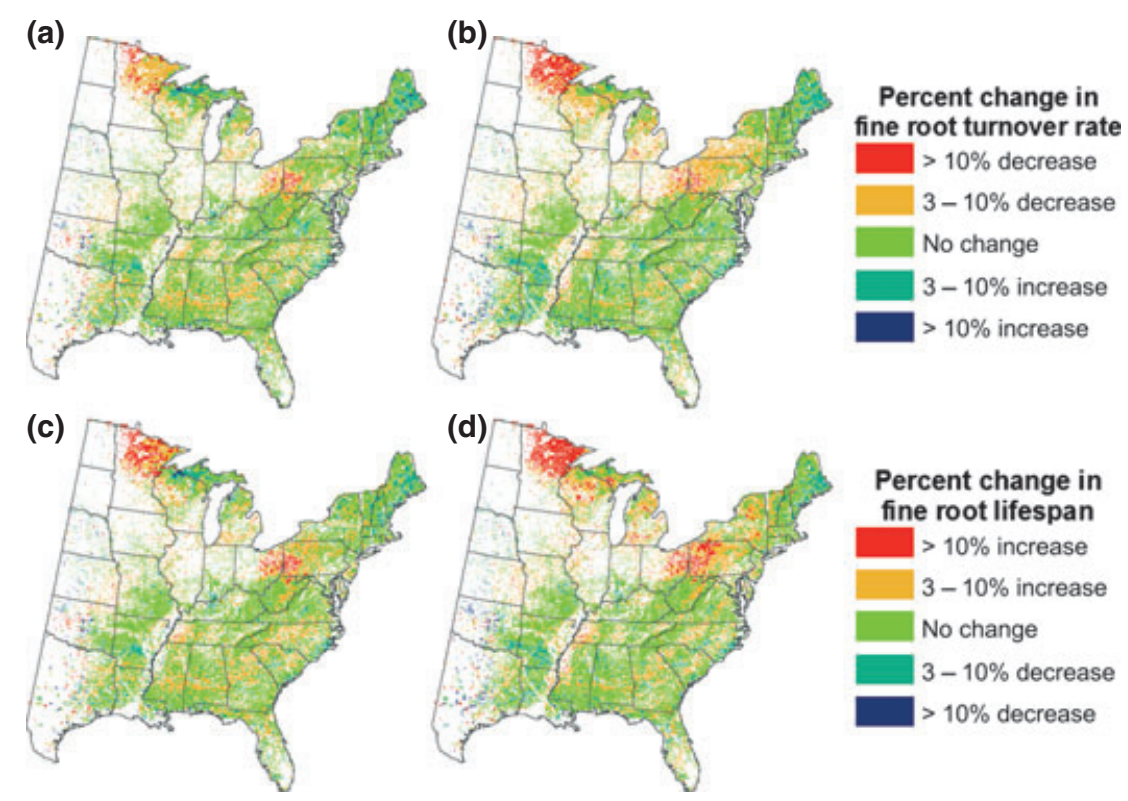

Fig. 4 Percent change in forest fine root turnover rates between current climate and future climate under a low $\mathrm{CO}_{2}$ emissions (a) and a high $\mathrm{CO}_{2}$ emissions scenario (b) and for percent change in fine root lifespan under low $\mathrm{CO}_{2}$ emissions (c) and a high $\mathrm{CO}_{2}$ emissions (d) scenarios.

with relatively fast turnover rates including Betula spp., Picea spp., P. balsamea, P. tremuloides, and P. serotina, and many species with relatively slow turnover rates (A. balasmea, A. saccharum, and T. canadensis). However, some of these shifts may be partially offset with possible range expansions for species like L. styraciflua, Q. stellata, and Pinus taeda.

\section{Model uncertainty}

The uncertainty score is a combination of the model confidence estimate $(M C)$ and the total amount of importance value covered $\left(I V_{c o v}\right)$ in a given grid cell. While the total IV covered is a direct estimate of the percent of trees accounted for in the model, using $\left(I V_{c o v}\right)$ alone to express model uncertainty yields an overly optimistic impression of model predictions with relatively high total IV covered across most of the eastern US (Fig. S1). The broad coverage then increases with the future climate scenarios such that under the high $\mathrm{CO}_{2}$ emissions scenario only a narrow band in the central US stands out with low amounts of $\left(I V_{c o v}\right)$. The MC estimate combines estimates of confidence from the predicted species distributions from DISTRIB and from the estimates of root dynamics. Results from $M C$ estimates highlighted greater uncertainty across the study area than indicated from $I V_{c o v}$ (Fig. S2). This occurs as some of the species included in the model may have relatively little data available to define and constrain their predicted spatial distributions in the
DISTRIB model and/or little or no direct observations of their fine root dynamics. Together, the $M C$ estimate combined with $\mathrm{IV}_{\text {cov }}$ yielded a more conservative estimate of the relative uncertainty across the study.

Across the eastern US, uncertainty was lowest (highest score) in the southeastern US and along the Appalachian Mountains into the northeast (Fig. 5). Uncertainty was also relatively low in the areas around northern Minnesota, Wisconsin, and Michigan that were anticipated to see shifts in root lifespan and turnover under future climate scenarios. Uncertainty was highest (lowest score) throughout the central plains states and through parts of Indiana, Illinois, and Ohio. These areas of uncertainty generally correspond with regions of intense agriculture and relatively low forest canopy cover.

\section{Discussion}

\section{Patterns of fine root lifespan and turnover}

Fine root dynamics are an integral part of ecosystem functioning and are important for understanding patterns of terrestrial C, water, and nutrient fluxes. However, data regarding fine root lifespan and turnover are difficult to obtain and comparisons across studies can be problematic. To our knowledge, no study has previously described patterns of root lifespan and turnover in a way that is both spatially explicit and based on direct observations of root dynamics and associated 

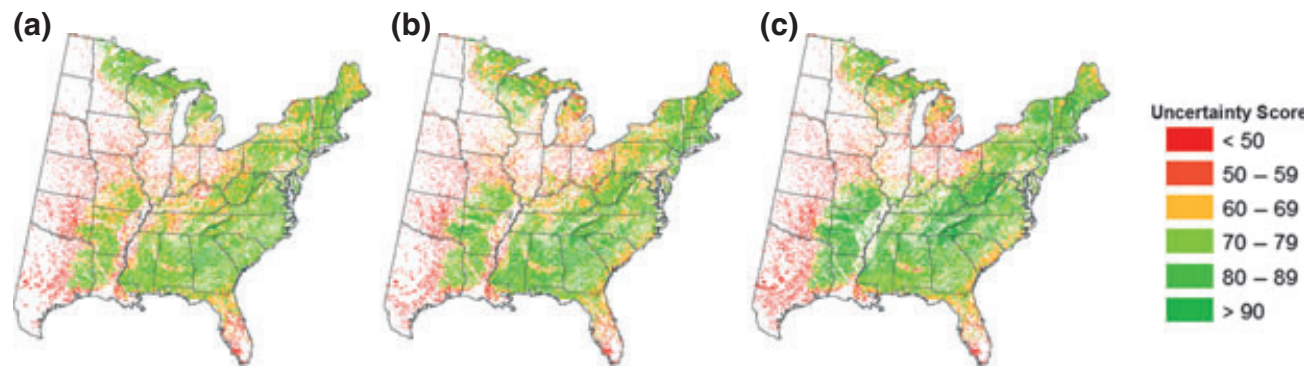

Fig. 5 Relative uncertainty scores for estimates of forest fine root lifespan and turnover rate across the eastern United State under current (a), future low $\mathrm{CO}_{2}$ emissions (b), and future high $\mathrm{CO}_{2}$ emissions climate scenarios (c). Lower numbers (red areas) represent greater uncertain while higher numbers (green areas) represent less uncertainty.

root and plant traits. Here, we combined predicted current distributions and distributions of future suitable habitat for tree species across the eastern US from the DISTRIB model with species-specific estimates of root lifespan and turnover. We found distinct patterns of root dynamics across the study area that could often be attributed to relatively high abundances of certain tree species. We also identified several regions that appeared likely to experience substantial changes in forest fine root turnover and root lifespan if species distributions shift in the future. However, the overall average rate of fine root turnover may remain stable across the eastern US despite the potential for altered species compositions with global climate change. Beyond providing potentially useful estimates of root dynamics for models operating at regional to continental scales, information regarding the patterning and potential shifts in fine root dynamics should improve understanding of many important processes in terrestrial systems.

At its most basic level, information describing fine root lifespan and turnover tell us how long fine roots live and how frequently populations of fine roots are replaced. In other words, these factors describe how rapidly root $C$ moves from the live, plant $C$ pool into dead, soil organic matter (SOM). However, root lifespan and turnover also have important impacts on rates of C accrual in SOM (Rasse et al., 2005; Tefs \& Gleixner, 2012) and the potential uptake (Nobel et al., 1990; Volder et al., 2005) and cycling (Aerts et al., 1992; Silver \& Miya, 2001) of nutrients and water. With better understanding of root dynamics, what inferences can be made regarding these processes across a landscape? Evidence from other studies has suggested that increased rates of $\mathrm{C}$ flux through fine roots acts to 'prime' or alter microbial communities which can increase nutrient cycling and speed the breakdown of labile and more recalcitrant forms of SOM (Wardle et al., 2004; Carney et al., 2007; Drake et al., 2011). It is therefore possible that shifting rates of turnover with climate change may result in wide reaching impacts on ecosystem structure and function. In the absence of other global change factors, increasing root turnover rates in the New England region or decreasing rates in the mid-Atlantic and in northern Minnesota could be responsible for changes in rates of soil C storage, shifts in mycorrhizal and bacterial communities, and altered nutrient cycling. Of course, these responses to climate change exist in a tight coupling with many other factors including altered precipitation, temperature, species composition, and litter quality in addition to absolute rates of turnover, or $\mathrm{C}$ flux from roots into soil. The potential connections between these environmental and biological factors with fine root dynamics should not be overlooked when considering ecosystem response to future climate.

\section{Model utility}

Most DGVMs and terrestrial biogeochemistry models operating at larger spatial scales (regional to global) describe root turnover across the eastern US as one or two broad plant functional types (PFTs; e.g., temperate broadleaf and evergreen needleleaf forests). Depending on the model, these PFTs or species may or may not vary in absolute rates of root turnover (Sitch et al., 2003; Tatarinov \& Cienciala, 2006). These simplifications are necessary to capture and describe broad patterns of vegetation change and $C$, nutrient, and water fluxes while still remaining analytically tractable. At the scale of our entire study area, this approach may be sufficient as the average turnover rate reported by the model across the eastern US remained stable between the different climate scenarios despite large predicted shifts in potential species distributions from the DISTRIB model (Iverson et al., 2008). However, at more regional scales these generalizations may not be sufficient as we observed greater than twofold difference in turnover rate across different areas within the eastern US. For example, estimated turnover rates in northern Minnesota approached $1.8 \mathrm{yr}^{-1}$ while for areas in the central US and parts of the southeastern US, turnover rates were consistently below $1.0 \mathrm{yr}^{-1}$ (Fig. 2). 
The next generation of models describing vegetation patterns and biogeochemistry are pushing the limits of understanding for how species interact and ecosystems or landscapes will react in the face of changing climate and disturbance (Shevliakova et al., 2009; Clark et al., 2011; French et al., 2011). However, as the spatial scale at which model output carries meaning decreases from continental to regional and finer scales, so too must the resolution of the information used to parameterize these models increase. Addressing our third objective, our approach describing potential patterns of root turnover and root lifespan presented here may provide a tool to help bridge the gap between broad PFT descriptions and fine-scale, species-specific parameters. This is of particular use as data describing root dynamics are extremely limited in most areas and can also be difficult to interpret or compare (McCormack, 2012). Across the study area used here, the typical one to two PFT approach could be further narrowed to five or six groups with different rates of fine root turnover. While this approach may be difficult to incorporate directly in current, broad PFT approaches, it may be used as models become more flexible and spatially explicit in their parameterization.

In addition to providing a first approximation of potential fine root turnover rates and root lifespan with current and future climate scenarios, this approach can easily incorporate other aspects not explicitly considered by the DISTRIB model that determine a species distribution and dominance. Human influences on land use, pest outbreaks, and many other factors will likely have a profound influence on species distributions in the eastern US and across the globe in the coming century (Defries et al., 1999; Houghton et al., 1999). Here, specific choices could be incorporated to allow the model to better reflect likely future species distributions and associated root dynamics. For example, in the southeastern US, Pinus palustris, a once dominant tree species now occupies less than $5 \%$ of its original habitat (Van Lear et al., 2005). However, should restoration efforts and changing timber practices lead to substantial replacement of other pine species like $P$. taeda and P. elliotii, this could be reflected in the model by adjusting predicted IVs for each species. Similarly, should the introduction of novel pests result in substantial reductions in the range and dominance of certain tree species (e.g., hemlock woolly adelgid; Spaulding \& Rieske (2010)), appropriate changes in species IVs could be adjusted to reflect anticipated species decline.

Currently, our model describing potential patterns of fine root lifespan and turnover rates is limited to operating in forested areas across the eastern US. However, the approach could theoretically be applied across any area where sufficient information regarding species distributions and species-specific estimates of root lifespan and turnover can be made available. Unfortunately, limited availability of root trait and root dynamics data will likely prevent application outside the current area for some time. Indeed, there is tremendous opportunity to improve understanding of ecosystem and larger scale biogeochemistry through directed efforts to observe and understand fine root dynamics in a greater range of species and ecosystems.

\section{Limitations and model uncertainty}

Our efforts to model and describe broad patterns of fine root lifespan and turnover are novel and potentially powerful. However, there are several important limitations to the current approach. While there are several potential limitations to the DISTRIB model, these have been discussed previously here and elsewhere (Iverson et al., 2008, 2011). Additional uncertainties result from the root turnover and lifespan estimates. First, few direct observations of lifespan or turnover exist for many of the species used in this analysis. Preliminary approximations of root lifespan were made using relationships between root diameter, tree growth rate and wood density, and assumed similarities between congeneric species. While we expect that this procedure yields reasonable first-order approximations of root dynamics, it is no substitute for direct observation and should be recognized as such. In particular, several key species or groups of species whose root dynamics have not been observed directly warrant special attention and should be targeted for future observations given their prominence in regions of the eastern US such as T. canadensis and Betula spp. in more northern areas as well as more broadly distributed species groups like Ulmus spp. and many species of Quercus spp.

Beyond difficulty generating a single, reliable speciesspecific estimate of root lifespan or turnover, there is also poor understanding associated with how these estimates shift with changing climate and soil conditions. Evidence from several studies suggests that fine root dynamics can vary significantly within a species. For example, several studies have reported estimates of lifespan for loblolly pine forests, $P$. taeda, and these range from 181 days to 500 days (King et al., 2002; Pritchard et al., 2008). Similarly, root lifespan in longleaf pine, $P$. palustris, has been reported to be roughly 200 days and as high as 400 days (Guo et al., 2008; Espeleta et al., 2009). While some of the differences in reported estimates may be due to differences in methodology, much is likely due to environmental differences experienced by the study trees. In general, it is expected that sitespecific differences in soil factors (e.g., texture, $\mathrm{pH}$, 
nutrient availability) and climate (e.g., averages and variability in temperature and precipitation) will have profound impacts on root dynamics (Eissenstat et al., In press). However, we have relatively little understanding of the magnitude, and in some cases, the direction of change in response to one or multiple interacting factors (but see Aber et al. (1985), Bai et al. (2010, 2012)). Furthermore, there is increasing evidence that even within a single site, fine root production and turnover can shift significantly between years (Iversen et al., 2008; Ferguson \& Nowak, 2011; McCormack, 2012). For these reasons, results from this combined model should not be applied or interpreted at ecosystem scales. Rather, these results should only be used to describe patterns closer to regional scales where ecosystem scale variability may be secondary to broad-scale patterns.

Finally, descriptions of fine root lifespan and turnover presented here apply only to the short-lived, more ephemeral fine roots within the broader, operationally defined fine root pool $(\leq 2 \mathrm{~mm})$. Ephemeral fine roots primarily represent the first- and second-order roots (i.e., the most distal portion of the root system) (Pregitzer et al., 2002), and are responsible for the majority of nutrient and water uptake by plants. These roots are also more dynamic and have faster turnover (typical range of $0.5-2.5 \mathrm{yr}^{-1}$ ) and often represent a greater flux of $C$ than the more persistent, longer lived fine root pool which has slower turnover (typical range of $0.1-$ $0.4 \mathrm{yr}^{-1}$ ), but represents a larger pool of standing C. While both groups are often classified together simply as 'fine roots', these should ideally be separated in modeling applications, thereby improving descriptions of C flux through roots (Riley et al., 2009; Gaudinski et al., 2010; Parton et al., 2010) and potentially enabling better understanding of nutrient and water uptake. However, if only a single pool of fine roots is used, then the turnover rates presented here would likely overestimate the total $\mathrm{C}$ flux through the fine root pool as they are only relevant to a limited portion of the fine root pool (Gaudinski et al., 2010).

In conclusion, our study suggest that even within a limited range of plant functional types, broad patterns of fine root turnover and lifespan likely exist at regional scales. Furthermore, altered climate regimes may lead to significant shifts in forest fine root turnover and lifespan due to compositional changes in dominant tree species. These patterns and potential future changes will be important to incorporate into model descriptions of belowground $\mathrm{C}$ allocation. The approach used here is flexible and may be applied to other study areas, but is contingent on sufficient data to describe species distributions and root dynamics. In general, data describing root dynamics are woefully inadequate and patterns describing trends across spe- cies are only beginning to emerge and are still limited. Future efforts should focus on observing and reporting fine root dynamics across a greater range of species and across different sites. Here, special attention should be paid to how environmental factors mediate root dynamics and what consistent trends can be described across common environmental gradients in soil and climate.

\section{Acknowledgements}

The authors would like to thank E. Crisfield and the LEAPS lab for support and expertise and helpful comments from three anonymous reviewers. This work was supported by the U.S. Department of Energy Office of Science (NICCR Award 3819) to EAHS, the U.S. National Science Foundation (Grants IOS0824704 and ARC1107381) to DME and the U.S. Department of Energy Graduate GREF to MLM.

\section{References}

Aber JD, Melillo JM, Nadelhoffer KJ, Mcclaugherty CA, Pastor J (1985) Fine root turnover in forest ecosystems in relation to quantity and form of nitrogen availabilitya comparison of 2 methods. Oecologia, 66, 317-321.

Aerts R, Bakker C, Decaluwe H (1992) Root turnover as determinant of the cycling of C, N, and P in a dry heathland ecosystem. Biogeochemistry, 15, 175-190.

Bai W, Wan S, Niu S et al. (2010) Increased temperature and precipitation interact to affect root production, mortality, and turnover in a temperate steppe: implications for ecosystem C cycling. Global Change Biology, 16, 1306-1316.

Bai WM, Xia JY, Wan SQ, Zhang WH, Li LH (2012) Day and night warming have different effect on root lifespan. Biogeosciences, 9, 375-384.

Burns RM, Honkala BH (eds) (1990a) Silvics of North America, Volume 2, Hardwoods. In: Agricultural Handbook 654. United States Department of Agriculture, Forest Service, Washington, DC

Burns RM, Honkala BH (eds) (1990b) Silvics of North America. Volume 1. Conifers. In: Agriculture Handbook 654. United States Department of Agriculture, Forest Service, Washington, DC.

Burton AJ, Pregitzer KS, Hendrick RL (2000) Relationships between fine root dynamics and nitrogen availability in Michigan northern hardwood forests. Oecologia, 125, 389-399.

Carney KM, Hungate BA, Drake BG, Megonigal JP (2007) Altered soil microbial community at elevated $\mathrm{CO}(2)$ leads to loss of soil carbon. National Academy of Sciences U S A, 104, 4990-4995.

Ciais P, Schelhaas MJ, Zaehle S et al. (2008) Carbon accumulation in European forests. Nature Geoscience, 1, 425-429.

Clark DB, Mercado LM, Sitch S et al. (2011) The Joint UK Land Environment Simulator (JULES), model description - Part 2: carbon fluxes and vegetation dynamics. Geoscientific Model Development, 4, 701-722.

Defries RS, Field CB, Fung I, Collatz GJ, Bounoua L (1999) Combining satellite data and biogeochemical models to estimate global effects of human-induced land cover change on carbon emissions and primary productivity. Global Biogeochemical Cycles, 13, 803-815.

Dixon RK, Solomon A, Brown S, Houghton R, Trexier M, Wisniewski J (1994) Carbon pools and flux of global forest ecosystems. Science, 263, 185.

Drake JE, Gallet-Budynek A, Hofmockel KS et al. (2011) Increases in the flux of carbon belowground stimulate nitrogen uptake and sustain the long-term enhancement of forest productivity under elevated CO. Ecology Letters, 14, 349-357.

Eissenstat DM, Mccormack ML, Du Q (In press) Global change and root lifespan. In: Plant Roots: The Hidden Half, 4th edn (eds Eshel A, Beeckman T), in press.

Espeleta JF, West JB, Donovan LA (2009) Tree species fine-root demography parallels habitat specialization across a sandhill soil resource gradient. Ecology, 90, 1773-1787.

Fan S, Gloor M, Mahlman J, Pacala S, Sarmiento J, Takahashi T, Tans P (1998) A large terrestrial carbon sink in North America implied by atmospheric and oceanic carbon dioxide data and models. Science, 282, 442-446. 
Ferguson SD, Nowak RS (2011) Transitory effects of elevated atmospheric $\mathrm{CO}_{2}$ on fine root dynamics in an arid ecosystem do not increase long-term soil carbon input from fine root litter. New Phytologist, 190, 953-967.

French NHF, Goovaerts P, Kasischke ES (2004) Uncertainty in estimating carbon emissions from boreal forest fires. Journal of Geophysical Research, 109, D14S08. doi: $10.1029 / 2003 J D 003635$.

Gaudinski JB, Torn MS, Riley WJ, Dawson TE, Joslin JD, Majdi H (2010) Measuring and modeling the spectrum of fine-root turnover times in three forests using isotopes, minirhizotrons, and the Radix model. Global Biogeochemical Cycles, 24, GB3029. doi: 10.1029/2009GB003649.

Goodale CL, Lajtha K, Nadelhoffer KJ, Boyer EW, Jaworski NA (2002) Forest nitrogen sinks in large eastern US watersheds: estimates from forest inventory and an ecosystem model. Biogeochemistry, 57, 239-266.

Grier CC, Vogt KA, Keyes MR, Edmonds RL (1981) Biomass distribution and aboveground and below-ground production in young and mature Abies-Amabilis zone ecosystems of the Washington cascades. Canadian Journal of Forest Research-Revue Canadienne De Recherche Forestiere, 11, 155-167.

Guo D, Mitchell RJ, Withington JM, Fan P-P, Hendricks JJ (2008) Endogenous and exogenous controls of root life span, mortality and nitrogen flux in a longleaf pine forest: root branch order predominates. Journal of Ecology, 96, 737-745.

Homer C, Huang CQ, Yang LM, Wylie B, Coan M (2004) Development of a 2001 National Land-Cover Database for the United States. Photogrammetric Engineering and Remote Sensing, 70, 829-840.

Houghton RA, Hackler JL, Lawrence KT (1999) The US carbon budget: contributions from land-use change. Science, 285, 574-578.

Iversen CM (2010) Digging deeper: fine root responses to rising atmospheric CO2 concentration in forested ecosystems. New Phytologist, 186, 346-357.

Iversen CM, Ledford J, Norby RJ (2008) $\mathrm{CO}_{2}$ enrichment increases carbon and nitrogen input from fine roots in a deciduous forest. New Phytologist, 179, 837-847.

Iverson LR, Prasad AM, Matthews SN, Peters M (2008) Estimating potential habitat for 134 eastern US tree species under six climate scenarios. Forest Ecology and Management, 254, 390-406.

Iverson LR, Prasad AM, Matthews SN, Peters MP (2011) Lessons learned while integrating habitat, dispersal, disturbance, and life-history traits into species habitat models under climate change. Ecosystems, 14, 1005-1020.

Jackson RB, Mooney HA, Schulze ED (1997) A global budget for fine root biomass, surface area, and nutrient contents. Proceedings of the National Academy of Sciences, 95, 7362-7366.

Jackson RB, Schenk HJ, Jobbagy EG et al. (2000) Belowground consequences of vegetation change and their treatment in models. Ecological Applications, 10, $470-483$

Jackson RB, Jobbágy EG, Avissar R et al. (2005) Trading water for carbon with biological carbon sequestration. Science, 310, 1944.

Kim Y, Knox RG, Longo M et al. (2012) Seasonal carbon dynamics and water fluxes in an Amazon rainforest. Global Change Biology, 18, 1322-1334.

King JS, Albaugh TJ, Allen HL, Buford M, Strain BR, Dougherty P (2002) Belowground carbon input to soil is controlled by nutrient availability and fine root dynamics in loblolly pine. New Phytologist, 154, 389-398.

Kucharik CJ, Barford CC, El Maayar M, Wofsy SC, Monson RK, Baldocchi DD (2006) A multiyear evaluation of a Dynamic Global Vegetation Model at three AmeriFlux forest sites: vegetation structure, phenology, soil temperature, and $\mathrm{CO}_{2}$ and $\mathrm{H}_{2} \mathrm{O}$ vapor exchange. Ecological Modelling, 196, 1-31.

Majdi H, Pregitzer K, Morén A-S, Nylund J-E, Ågren GI (2005) Measuring Fine Root Turnover in Forest Ecosystems. Plant and Soil, 276, 1-8.

Malhi Y, Doughty C, Galbraith D (2011) The allocation of ecosystem net primary productivity in tropical forests. Philosophical Transactions of the Royal Society B: Biological Sciences, 366, 3225-3245.

McCormack ML (2012) Measuring and modeling fine root dynamics in temperate forests. Dissertation, The Pennsylvania State University.

McCormack ML, Adams TS, Smithwick EA, Eissensat DM (2012) Predicting fine root lifespan from plant functional traits in temperate trees. New Phytologist, 195, 823 831.

Medvigy D, Wofsy SC, Munger JW, Hollinger DY, Moorcroft PR (2009) Mechanistic scaling of ecosystem function and dynamics in space and time: Ecosystem Demography model version 2. Journal of Geophysical Research-Biogeosciences, 114, G01002.
Nobel PS, Schulte PJ, North GB (1990) Water influx characteristics and hydraulic conductivity for roots of Agave deserti Engelm. Journal of Experimental Botany, 41, 409415

Ostle NJ, Smith P, Fisher R et al. (2009) Integrating plant-soil interactions into global carbon cycle models. Journal of Ecology, 97, 851-863.

Pan YD, Birdsey RA, Fang JY et al. (2011) A large and persistent carbon sink in the world's forests. Science, 333, 988-993.

Parton WJ, Hanson PJ, Swanston C, Torn M, Trumbore SE, Riley W, Kelly R (2010) ForCent model development and testing using the Enriched Background Isotope Study experiment. Journal of Geophysical Research-Biogeosciences, 115, G04001. doi: 10.1029/2009JG001193

Prasad AM, Iverson LR, Liaw A (2006) Newer classification and regression tree techniques: bagging and random forests for ecological prediction. Ecosystems, 9, 181-199.

Prasad AM, Iverson LR, Matthews S, Peters M (2007) A climate change atlas for 134 forest tree species of the eastern United States [database]. Northern Research Station, USDA Forest Service, Delaware OH. Available at: http://www.nrs.fs.fed.us/ atlas/tree(accessed September 2012).

Pregitzer KS, Deforest JL, Burton AJ, Allen MF, Ruess RW, Hendrick RL (2002) Fine root architecture of nine North American trees. Ecological Monographs, 72, 293-309.

Pritchard SG, Strand AE, Mccormack ML et al. (2008) Fine root dynamics in a loblolly pine forest are influenced by free-air- $\mathrm{CO}_{2}$-enrichment: a six-year-minirhizotron study. Global Change Biology, 14, 588-602.

Rasse DP, Rumpel C, Dignac MF (2005) Is soil carbon mostly root carbon? Mechanisms for a specific stabilisation. Plant and Soil, 269, 341-356.

Richter DD, Markewitz D, Trumbore SE, Wells CG (1999) Rapid accumulation and turnover of soil carbon in a re-establishing forest. Nature, 400, 56-58.

Riley WJ, Gaudinski JB, Torn MS, Joslin JD, Hanson PJ (2009) Fine-root mortality rates in a temperate forest: estimates using radiocarbon data and numerical modeling. New Phytologist, 184, 387-398.

Schimel DS (1995) Terrestrial ecosystems and the carbon-cycle. Global Change Biology, 1,77-91.

Shevliakova E, Pacala SW, Malyshev S et al. (2009) Carbon cycling under 300 years of land use change: importance of the secondary vegetation sink. Global Biogeochemical Cycles, 23, GB2022. doi: 10.1029/2007GB003176

Silver WL, Miya RK (2001) Global patterns in root decomposition: comparisons of climate and litter quality effects. Oecologia, 129, 407-419.

Sitch S, Smith B, Prentice IC et al. (2003) Evaluation of ecosystem dynamics, plant geography and terrestrial carbon cycling in the LPJ dynamic global vegetation model. Global Change Biology, 9, 161-185.

Smithwick EAH, Kashian DM, Ryan MG, Turner MG (2009) Long-Term Nitrogen Storage and Soil Nitrogen Availability in Post-Fire Lodgepole Pine Ecosystems. Ecosystems, 12, 792-806.

Spaulding HL, Rieske LK (2010) The aftermath of an invasion: structure and composition of Central Appalachian hemlock forests following establishment of the hemlock woolly adelgid, Adelges tsugae. Biological Invasions, 12, 3135 3143.

Tatarinov FA, Cienciala E (2006) Application of BIOME-BGC model to managed forests 1 . Sensitivity analysis. Forest Ecology and Management, 237, 267-279.

Tefs C, Gleixner G (2012) Importance of root derived carbon for soil organic matter storage in a temperate old-growth beech forest - Evidence from C, N and C-14 content. Forest Ecology and Management, 263, 131-137.

Van Lear D, Carroll W, Kapeluck P, Johnson R (2005) History and restoration of the longleaf pine-grassland ecosystem: implications for species at risk. Forest Ecology and Management, 211, 150-165.

Vitousek P (1982) Nutrient Cycling and Nutrient Use Efficiency. American Naturalist, 119, 553-572.

Volder A, Smart DR, Bloom AJ, Eissenstat DM (2005) Rapid decline in nitrate uptake and respiration with age in fine lateral roots of grape: implications for root efficiency and competitive effectiveness. New Phytologist, 165, 493-501.

Wardle DA, Bardgett RD, Klironomos JN, Setälä H, Van Der Putten WH, Wall DH (2004) Ecological linkages between aboveground and belowground biota. Science, 304, 1629-1633.

Zanne AE, Lopez-Gonzalez G, Coomes DA et al. (2009) Global wood density database, Dryad. www.datadryad.org. 


\section{Supporting Information}

Additional Supporting Information may be found in the online version of this article:

Figure S1. Total importance value (IV) covered across the eastern United State under current (a), future low $\mathrm{CO}_{2}$ emissions (b), and future high $\mathrm{CO}_{2}$ emissions climate scenarios (c). Lower numbers (red areas) occur in areas where less of the total forest trees were included in the analysis and higher numbers (green areas) occur in areas where more of the total forest trees were included in the analysis.

Figure S2. Relative model confidence for estimates of forest fine root lifespan and turnover rate across the eastern United State under current (a), future low $\mathrm{CO}_{2}$ emissions (b), and future high $\mathrm{CO}_{2}$ emissions climate scenarios (c). Lower numbers (green areas) represent greater confidence while higher numbers (red areas) represent less confidence.

Table S1. Table of all lifespan and turnover estimates for each species along with citations and justification. $C D_{i}$ is the DISTRIB model reliability score and $C R_{i}$ is the confidence estimate for estimates of fine root turnover over and lifespan. Where $C R_{i}$ equals one, the lifespan and or turnover values were taken directly from published literature reporting root dynamics for that species. Where $C R_{i}$ equals two, lifespan estimates were based on estimates from available congeneric species and may have then been adjusted higher or lower based on plant traits (growth rate and/or wood density). Where $C R_{i}$ equals three, first approximations of root lifespan and turnover were generated based on root and whole-plant traits. Original turnover estimates were generated based directly on Eqn (1). Final Adjusted estimates took Eqn (2) into account where appropriate. 


\section{Supplemental Text 1.}

The uncertainty score is based on model confidence $(M C)$ and the total importance value covered $\left(I V_{C o v}\right)$ for a given grid cell. The final $\sigma$ is theoretically scaled from 0 to 100 but combines the $M C$ with $I V_{C o v}$, which are not initially on the same scale. $M C$ is scaled from 1 to 9 with 1 being the most confident and 9 the least while $I V_{C o v}$ is scaled from 0 to 100 with 0 being no IV covered and 100 being all trees in a given grid cell are included in the analysis. First, both $M C$ and $I V_{C o v}$ are scaled to be between 0 and 1, with 1 being the most confident or complete IV covered. These estimates are summed and rescaled to between 0 and 1 by dividing by 2 . The final estimate is scaled to between 0 and 100 by multiplying by 100 .

$$
\sigma=\left(\left(\frac{1}{M C}+\frac{I V_{C o v}}{100}\right) \div 2\right) * 100=\left(\frac{1}{M C * 2}+\frac{I V_{C o v}}{200}\right) * 100=\left(\frac{50}{M C}+\frac{I V_{C o v}}{2}\right)
$$


Figure S1. Total importance value (IV) covered across the eastern United State under current (a), future low $\mathrm{CO}_{2}$ emissions (b), and future high $\mathrm{CO}_{2}$ emissions climate scenarios (c). Lower numbers (red areas) occur in areas where less of the total forest trees were included in the analysis and higher numbers (green areas) occur in areas where more of the total forest trees were included in the analysis.
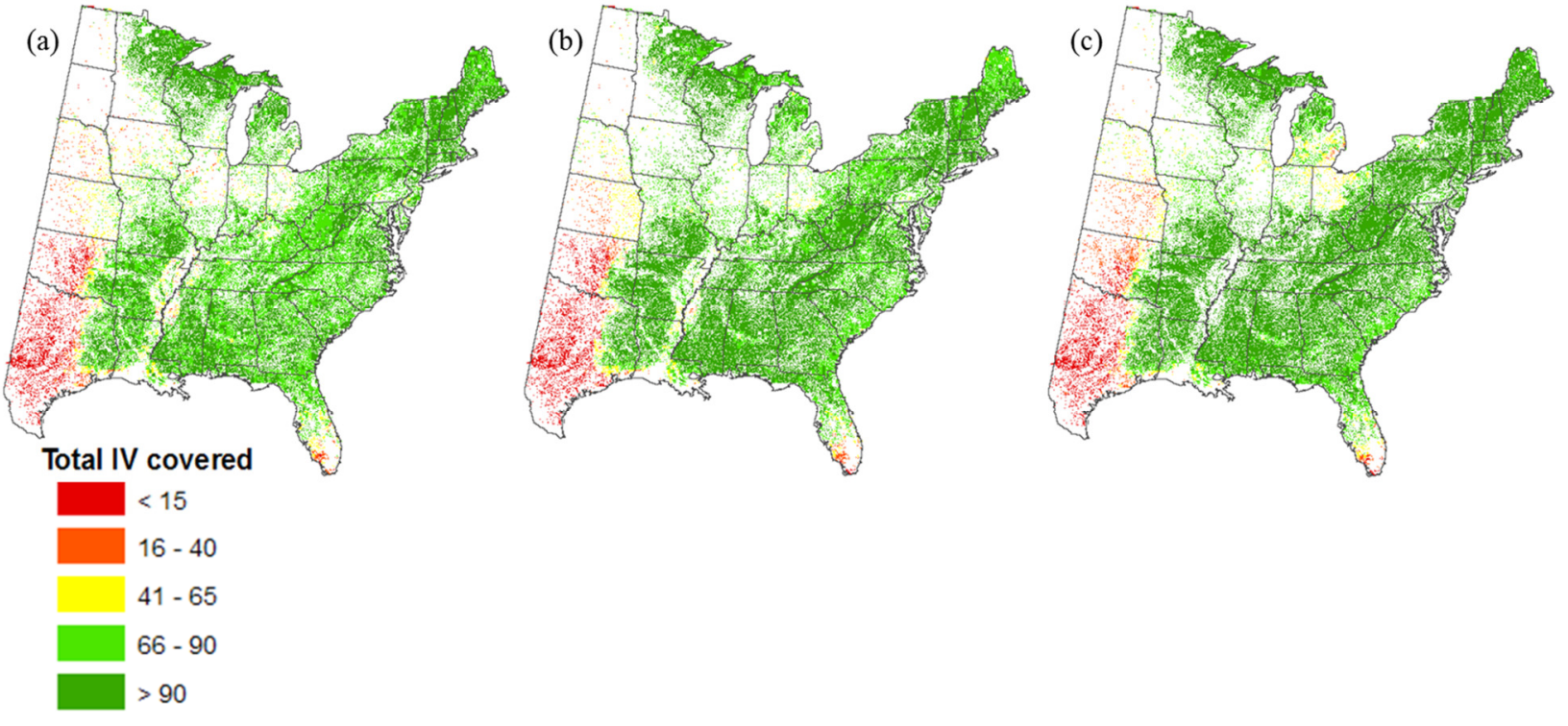
Figure S2. Relative model confidence for estimates of forest fine root lifespan and turnover rate across the eastern United State under current (a), future low $\mathrm{CO}_{2}$ emissions (b), and future high $\mathrm{CO}_{2}$ emissions climate scenarios (c). Lower numbers (green areas) represent greater confidence while higher numbers (red areas) represent less confidence in.
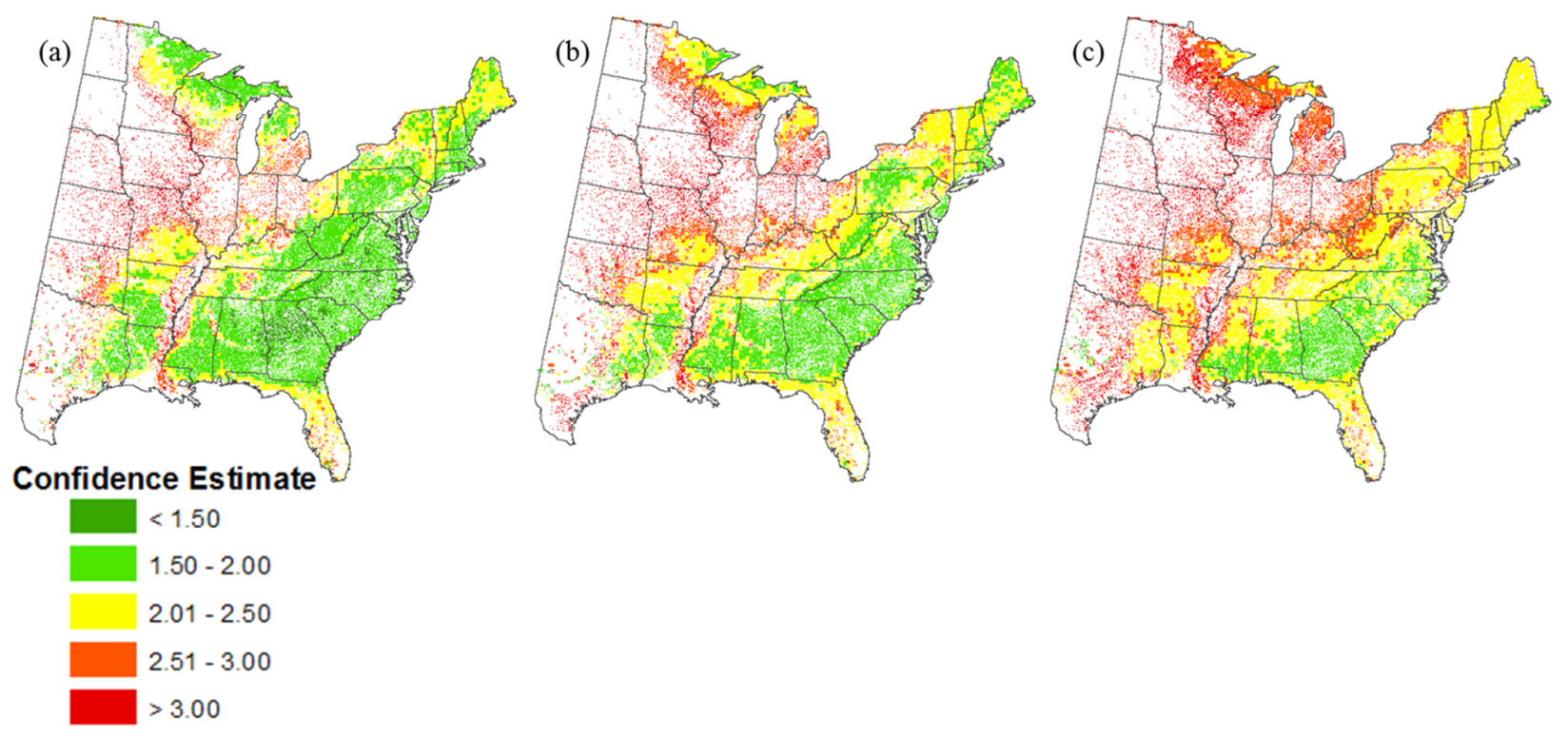
Table S1. Table of all lifespan and turnover estimates for each species along with citations and justification. $C D_{i}$ is the DISTRIB model reliability score and $C R_{i}$ is the confidence estimate for estimates of fine root turnover over and lifespan. Where $C R_{i}$ equals 1 , the lifespan and or turnover values were taken directly from published literature reporting root dynamics for that species. Where $C R_{i}$ equals 2 , lifespan estimates were based on estimates from available congeneric species and may have then been adjusted higher or lower based on plant traits (growth rate and/or wood density). Where $C R_{i}$ equals 3, first approximations of root lifespan and turnover were generated based on root and whole-plant traits. Original turnover estimates were generated based directly on equation 1 . Final adjusted estimates took equation 2 into account when estimated root lifespans exceeded one year

\begin{tabular}{|c|c|c|c|c|c|c|}
\hline \multirow[t]{2}{*}{ Species } & \multirow[t]{2}{*}{$C D_{i}$} & \multirow[t]{2}{*}{$C R_{i}$} & \multirow{2}{*}{$\begin{array}{l}\text { Lifespan } \\
\text { (days), } \boldsymbol{L}_{\boldsymbol{F} S}\end{array}$} & \multicolumn{2}{|c|}{$\begin{array}{l}\text { Turnover }\left(\mathrm{yr}^{-1}\right) \\
\mathrm{T}_{F S}\end{array}$} & \multirow[t]{2}{*}{ Notes and Citations for root lifespan/turnover } \\
\hline & & & & Original & Final & \\
\hline Abies balsamea & 1 & 2 & 375 & 0.75 & 0.75 & $\begin{array}{l}\text { Based on A. alba from Withington et al. (2006) (413 days), biased down due } \\
\text { to potential slow decomposition at site }\end{array}$ \\
\hline Acer barbatum & 2 & 2 & 300 & 1.07 & 1.07 & Based on A. rubrum and A. saccharum from McCormack et al. (2012) \\
\hline Acer negundo & 2 & 1 & 190 & 1.55 & 1.40 & McCormack et al. (2012); McCormack et al. (Internal review) \\
\hline Acer nigrum & 3 & 2 & 320 & 0.99 & 0.99 & Based on A. saccharum from McCormack et al. (2012) \\
\hline Acer pensylvanicum & 1 & 2 & 190 & 1.55 & 1.55 & Based on A. negundo from McCormack et al. (2012) \\
\hline Acer rubrum & 1 & 1 & 259 & 1.25 & 1.20 & McCormack et al. (2012); McCormack et al. (Internal review) \\
\hline Acer saccharinum & 2 & 2 & 190 & 1.55 & 1.55 & Based on A. negundo from McCormack et al. (2012) \\
\hline Acer saccharum & 1 & 1 & 324 & 0.97 & 0.97 & McCormack et al. (2012); McCormack et al. (Internal review) \\
\hline Acer spicatum & 1 & 2 & 190 & 1.55 & 1.55 & Based on A. negundo from McCormack et al. (2012) \\
\hline Betula alleghaniensis & 1 & 3 & 190 & 1.55 & 1.55 & $\begin{array}{l}\text { Slower growing, finely rooted, medium wood density; Crabtree and } \\
\text { Bernston (1994); Yanai et al. (2008); Zanne et al. (2009) }\end{array}$ \\
\hline Betula lenta & 1 & 3 & 165 & 1.65 & 1.65 & $\begin{array}{l}\text { Medium growing, finely rooted, medium wood density; Crabtree and } \\
\text { Bernston (1994); Yanai et al. (2008); Zanne et al. (2009) }\end{array}$ \\
\hline Betula nigra & 3 & 3 & 140 & 1.76 & 1.76 & $\begin{array}{l}\text { Fast growing, finely rooted, medium wood density; Crabtree and Bernston } \\
\text { (1994); Yanai et al. (2008); Zanne et al. (2009) }\end{array}$ \\
\hline Betula papyrifera & 1 & 3 & 140 & 1.76 & 1.76 & $\begin{array}{l}\text { Fast growing, finely rooted, medium wood density; Crabtree and Bernston } \\
\text { (1994); Yanai et al. (2008); Zanne et al. (2009) }\end{array}$ \\
\hline Betula populifolia & 2 & 3 & 140 & 1.76 & 1.76 & $\begin{array}{l}\text { Fast growing, finely rooted, medium wood density; Crabtree and Bernston } \\
\text { (1994); Yanai et al. (2008); Zanne et al. (2009) }\end{array}$ \\
\hline
\end{tabular}




\begin{tabular}{|c|c|c|c|c|c|c|}
\hline \multirow[t]{2}{*}{ Species } & \multirow[t]{2}{*}{$C D_{i}$} & \multirow[t]{2}{*}{$C R_{i}$} & \multirow{2}{*}{$\begin{array}{l}\text { Lifespan } \\
\text { (days), } \boldsymbol{L}_{\boldsymbol{F} S}\end{array}$} & \multicolumn{2}{|c|}{$\begin{array}{l}\text { Turnover }\left(\mathrm{yr}^{-1}\right) \\
\mathrm{T}_{\boldsymbol{F} S}\end{array}$} & \multirow[t]{2}{*}{ Notes and Citations for root lifespan/turnover } \\
\hline & & & & Original & Final & \\
\hline Carpinus caroliniana & 2 & 3 & 290 & 1.12 & 1.12 & $\begin{array}{l}\text { Same family at Betuala (Betulaceae) but with higher wood density (Zanne et } \\
\text { al., 2009) }\end{array}$ \\
\hline Carya aquatica & 2 & 2 & 245 & 1.31 & 1.31 & Based on C. glabra from McCormack et al. (2012) \\
\hline Carya cordiformis & 3 & 2 & 247 & 1.30 & 1.45 & Based on C. glabra from McCormack et al. (2012) \\
\hline Carya glabra & 1 & 1 & 247 & 1.30 & 1.45 & McCormack et al. (2012); McCormack et al. (Internal review) \\
\hline Carya illinoinensis & 3 & 2 & 247 & 1.30 & 1.45 & Based on C. glabra from McCormack et al. (2012) \\
\hline Carya laciniosa & 3 & 2 & 247 & 1.30 & 1.45 & Based on C. glabra from McCormack et al. (2012) \\
\hline Carya ovata & 2 & 2 & 247 & 1.30 & 1.45 & Based on C. glabra from McCormack et al. (2012) \\
\hline Carya texana & 1 & 2 & 247 & 1.30 & 1.45 & Based on C. glabra from McCormack et al. (2012) \\
\hline Carya tomentosa & 1 & 2 & 247 & 1.30 & 1.45 & Based on C. glabra from McCormack et al. (2012) \\
\hline Fagus grandifolia & 1 & 2 & 200 & 1.50 & 1.35 & $\begin{array}{l}\text { Based on F. sylvatica from Withington et al. (2006); Mainiero and Kazda } \\
\text { (2006) }\end{array}$ \\
\hline Fraxinus americana & 1 & 2 & 330 & 0.94 & 1.40 & $\begin{array}{l}\text { Based on F. mandshurica from Shi et al. (2008); Yu et al. (2009); Xia et al. } \\
\text { (2010) }\end{array}$ \\
\hline Fraxinus nigra & 1 & 2 & 330 & 0.94 & 1.40 & $\begin{array}{l}\text { Based on F. mandshurica from Shi et al. (2008); Yu et al. (2009); Xia et al. } \\
\text { (2010) }\end{array}$ \\
\hline Fraxinus pennsylvanica & 2 & 2 & 330 & 0.94 & 1.40 & $\begin{array}{l}\text { Based on F. mandshurica from Shi et al. (2008); Yu et al. (2009); Xia et al. } \\
\text { (2010) }\end{array}$ \\
\hline Fraxinus quadrangulata & 3 & 2 & 330 & 0.94 & 1.40 & $\begin{array}{l}\text { Based on F. mandshurica from Shi et al. (2008); Yu et al. (2009); Xia et al. } \\
\text { (2010) }\end{array}$ \\
\hline Juglans cinerea & 3 & 2 & 207 & 1.47 & 1.47 & Based on J. nigra from (McCormack et al., 2012) \\
\hline Juglans nigra & 2 & 1 & 207 & 1.47 & 1.47 & McCormack et al. (2012); McCormack et al. (Internal review) \\
\hline Juniperus virginiana & 2 & 2 & 250 & 1.29 & 1.29 & $\begin{array}{l}\text { Based on Fig. } 6 \text { in Peek et al. (2006), with bias towards shallow roots; } J \text {. } \\
\text { virginiana may have coarser roots than J. osteosperma }\end{array}$ \\
\hline Larix laricina & 1 & 2 & 300 & 1.07 & 1.07 & Based on L. gmelinii from Shi et al. (2008) \\
\hline Liquidambar styraciflua & 1 & 1 & 115 & 2.00 & 2.00 & $\begin{array}{l}\text { Based on Iversen } \text { et al. (2008), and adjusted to reflect similar method for } \\
\text { calculating root turnover used for other species }\end{array}$ \\
\hline Liriodendron tulipifera & 1 & 1 & 323 & 0.97 & 0.97 & McCormack et al. (2012); McCormack et al. (Internal review) \\
\hline
\end{tabular}




\begin{tabular}{|c|c|c|c|c|c|c|}
\hline \multirow[t]{2}{*}{ Species } & \multirow[t]{2}{*}{$C D_{i}$} & \multirow[t]{2}{*}{$C R_{i}$} & \multirow{2}{*}{$\begin{array}{l}\text { Lifespan } \\
\text { (days), } \boldsymbol{L}_{\boldsymbol{F} S}\end{array}$} & \multicolumn{2}{|c|}{$\begin{array}{l}\text { Turnover }\left(\mathrm{yr}^{-1}\right) \\
\mathrm{T}_{\boldsymbol{F} S}\end{array}$} & \multirow[t]{2}{*}{ Notes and Citations for root lifespan/turnover } \\
\hline & & & & Original & Final & \\
\hline Magnolia acuminata & 1 & 2 & 270 & 1.20 & 1.20 & Fast growth rate with coarse roots \\
\hline Magnolia grandiflora & 2 & 2 & 325 & 0.97 & 0.97 & Moderate growth rate with coarse roots \\
\hline Magnolia virginiana & 1 & 1 & 301 & 1.07 & 1.07 & Wiseman and Wells (2009); Moderate growth with coarse roots \\
\hline Nyssa aquatica & 2 & 2 & 200 & 1.50 & 1.50 & $\begin{array}{l}\text { Based on Nyssa spp. from Symbula and Day Jr (1988) as interpreted by } \\
\text { (Gill \& Jackson, 2000) }\end{array}$ \\
\hline Nyssa sylvatica & 1 & 2 & 200 & 1.50 & 1.50 & $\begin{array}{l}\text { Based on Nyssa spp. from Symbula and Day Jr (1988) as interpreted by } \\
\text { (Gill \& Jackson, 2000) }\end{array}$ \\
\hline $\begin{array}{l}\text { Nyssa sylvatica var. } \\
\text { biflora }\end{array}$ & 1 & 2 & 200 & 1.50 & 1.50 & $\begin{array}{l}\text { Based on Nyssa spp. from Symbula and Day Jr (1988) as interpreted by } \\
\text { (Gill \& Jackson, 2000) }\end{array}$ \\
\hline Picea glauca & 2 & 2 & 250 & 1.29 & 1.29 & $\begin{array}{l}\text { Based on P. abies from Majdi and Kangas (1997); Majdi et al. (2005); } \\
\text { Persson and Stadenberg (2009) }\end{array}$ \\
\hline Picea mariana & 1 & 1 & 150 & 1.72 & 1.72 & Ruess et al. (2003) \\
\hline Picea rubens & 1 & 2 & 220 & 1.42 & 1.42 & $\begin{array}{l}\text { Based on P. abies, Majdi and Kangas (1997); Majdi et al. (2005); Persson } \\
\text { and Stadenberg (2009); faster growth than P.glauca }\end{array}$ \\
\hline Pinus banksiana & 1 & 2 & 300 & 1.07 & 1.07 & $\begin{array}{l}\text { Based on P. strobus and P. virginiana from (McCormack et al., 2012); } \\
\text { generic pine }\end{array}$ \\
\hline Pinus clausa & 2 & 2 & 375 & 0.75 & 0.75 & $\begin{array}{l}\text { Based on P. strobus and P. virginiana from (McCormack et al., 2012); } \\
\text { generic pine, slower growth rate }\end{array}$ \\
\hline Pinus echinata & 1 & 2 & 300 & 1.07 & 1.07 & $\begin{array}{l}\text { Based on P. strobus and P. virginiana from (McCormack et al., 2012); } \\
\text { generic pine }\end{array}$ \\
\hline Pinus elliottii & 1 & 2 & 280 & 1.16 & 1.16 & $\begin{array}{l}\text { Based on } P \text {. strobus and } P \text {. virginiana from (McCormack et al., 2012); } \\
\text { generic pine, faster growth rate }\end{array}$ \\
\hline Pinus glabra & 2 & 2 & 300 & 1.07 & 1.07 & $\begin{array}{l}\text { Based on P. strobus and P. virginiana from (McCormack et al., 2012); } \\
\text { generic pine }\end{array}$ \\
\hline Pinus palustris & 1 & 1 & 300 & 1.07 & 1.07 & $\begin{array}{l}\text { Based on Guo et al. (2008) - } 200 \text { days, and Espeleta et al. (2009)-400 days; } \\
\text { and (West et al., 2004) }\end{array}$ \\
\hline Pinus pungens & 2 & 2 & 350 & 0.86 & 0.86 & $\begin{array}{l}\text { Based on } P . \text { strobus and } P \text {. virginiana from (McCormack et al., 2012); } \\
\text { generic pine, slower growth rate }\end{array}$ \\
\hline Pinus resinosa & 2 & 1 & 250 & 1.29 & 1.29 & $\begin{array}{l}\text { Based on Coleman et al. (2000)-291 days and Zeleznik and Dickmann } \\
\text { (2004)-170 days }\end{array}$ \\
\hline Pinus rigida & 1 & 2 & 300 & 1.07 & 1.07 & $\begin{array}{l}\text { Based on } P . \text { strobus and P. virginiana from (McCormack et al., 2012); } \\
\text { generic pine }\end{array}$ \\
\hline Pinus serotina & 1 & 2 & 350 & 0.86 & 0.86 & $\begin{array}{l}\text { Based on P. strobus and P. virginiana from (McCormack et al., 2012); } \\
\text { generic pine, slower growth rate }\end{array}$ \\
\hline
\end{tabular}




\begin{tabular}{|c|c|c|c|c|c|c|}
\hline \multirow[t]{2}{*}{ Species } & \multirow[t]{2}{*}{$C D_{i}$} & \multirow[t]{2}{*}{$C R_{i}$} & \multirow{2}{*}{$\begin{array}{c}\text { Lifespan } \\
\text { (days), } \boldsymbol{L}_{\boldsymbol{F} S}\end{array}$} & \multicolumn{2}{|c|}{$\begin{array}{l}\text { Turnover }\left(\mathrm{yr}^{-1}\right) \\
\mathrm{T}_{F S}\end{array}$} & \multirow[t]{2}{*}{ Notes and Citations for root lifespan/turnover } \\
\hline & & & & Original & Final & \\
\hline Pinus strobus & 1 & 1 & 296 & 1.09 & 1.09 & McCormack et al. (2012); McCormack et al. (Internal review) \\
\hline Pinus taeda & 1 & 1 & 370 & 0.77 & 0.77 & $\begin{array}{l}\text { (King et al., 2002), } 181 \text { days; Strand et al. (2008), } 365 \text { days and Pritchard } \text { et } \\
\text { al. (2008), biased to discount higher order roots }\end{array}$ \\
\hline Pinus virginiana & 1 & 1 & 283 & 1.15 & 1.15 & McCormack et al. (2012); McCormack et al. (Internal review) \\
\hline Populus balsamifera & 1 & 2 & 100 & 1.93 & 2.00 & Based on P. tremuloides from (McCormack et al., 2012) \\
\hline Populus deltoides & 3 & 1 & 450 & 0.43 & 0.70 & Based on Kern et al. (2004) and M. Coleman (unpublished) \\
\hline Populus grandidentata & 1 & 2 & 400 & 0.64 & 0.80 & Based on greater similarity to $P$. deltiodes \\
\hline Populus tremuloides & 1 & 1 & 95 & 1.95 & 2.05 & McCormack et al. (2012); McCormack et al. (Internal review) \\
\hline Prunus serotina & 1 & 2 & 115 & 1.87 & 1.87 & $\begin{array}{l}\text { Based on } P \text { avium from Baddeley and Watson (2005) and } P \text {. persica from } \\
\text { Wells et al. (2002) }\end{array}$ \\
\hline Quercus alba & 1 & 1 & 336 & 0.92 & 0.92 & McCormack et al. (2012); McCormack et al. (Internal review) \\
\hline Quercus bicolor & 3 & 2 & 275 & 1.18 & 1.18 & $\begin{array}{l}\text { Based on Q. alba from McCormack et al. (2012), white oak with faster } \\
\text { growth rate }\end{array}$ \\
\hline Quercus coccinea & 1 & 2 & 215 & 1.44 & 1.44 & $\begin{array}{l}\text { Based on } Q \text {. rubra from McCormack et al. (2012), red oak with faster } \\
\text { growth rate }\end{array}$ \\
\hline Quercus durandii & 3 & 2 & 300 & 1.07 & 1.07 & Based on Q. alba from McCormack et al. (2012) \\
\hline Quercus ellipsoidalis & 2 & 2 & 235 & 1.35 & 1.35 & $\begin{array}{l}\text { Based on Q. rubra from McCormack et al. (2012), red oak with moderate } \\
\text { growth rate }\end{array}$ \\
\hline $\begin{array}{l}\text { Quercus falcata } \\
\text { var.falcata }\end{array}$ & 1 & 2 & 235 & 1.35 & 1.35 & $\begin{array}{l}\text { Based on } Q . \text { rubra from McCormack et al. (2012), red oak with moderate } \\
\text { growth rate }\end{array}$ \\
\hline $\begin{array}{l}\text { Quercus falcata } \\
\text { var.pagodifolia }\end{array}$ & 2 & 2 & 235 & 1.35 & 1.35 & $\begin{array}{l}\text { Based on Q. rubra from McCormack et al. (2012), red oak with moderate } \\
\text { growth rate }\end{array}$ \\
\hline Quercus imbricaria & 2 & 2 & 235 & 1.35 & 1.35 & $\begin{array}{l}\text { Based on } Q \text {. rubra from McCormack et al. (2012), red oak with moderate } \\
\text { growth rate }\end{array}$ \\
\hline Quercus incana & 2 & 2 & 500 & 0.21 & 0.65 & Based on (Espeleta et al., 2009), biased to discount higher order roots \\
\hline Quercus laevis & 1 & 2 & 500 & 0.21 & 0.65 & Based on (Espeleta et al., 2009), biased to discount higher order roots \\
\hline Quercus laurifolia & 1 & 2 & 215 & 1.44 & 1.44 & $\begin{array}{l}\text { Based on } Q \text {. rubra from McCormack et al. (2012), red oak with faster } \\
\text { growth rate }\end{array}$ \\
\hline Quercus lyrata & 2 & 2 & 310 & 1.03 & 1.03 & $\begin{array}{l}\text { Based on } Q \text {. alba from McCormack et al. (2012), white oak with moderate } \\
\text { growth rate }\end{array}$ \\
\hline
\end{tabular}




\begin{tabular}{|c|c|c|c|c|c|c|}
\hline \multirow[t]{2}{*}{ Species } & \multirow[t]{2}{*}{$C D_{i}$} & \multirow[t]{2}{*}{$C R_{i}$} & \multirow{2}{*}{$\begin{array}{c}\text { Lifespan } \\
\text { (days), } \boldsymbol{L}_{\boldsymbol{F} S}\end{array}$} & \multicolumn{2}{|c|}{$\begin{array}{c}\text { Turnover }\left(\mathrm{yr}^{-1}\right) \\
\mathrm{T}_{F S}\end{array}$} & \multirow[t]{2}{*}{ Notes and Citations for root lifespan/turnover } \\
\hline & & & & Original & Final & \\
\hline Quercus macrocarpa & 2 & 2 & 350 & 0.86 & 0.86 & $\begin{array}{l}\text { Based on } Q . \text { alba from McCormack et al. (2012) and Tjoelker } \text { et al. (2005) } \\
360 \text { days, white oak with slow growth rate }\end{array}$ \\
\hline Quercus marilandica & 2 & 2 & 260 & 1.25 & 1.25 & $\begin{array}{l}\text { Based on } Q \text {. rubra from McCormack et al. (2012), red oak with slower } \\
\text { growth rate }\end{array}$ \\
\hline Quercus michauxii & 2 & 2 & 310 & 1.03 & 1.03 & $\begin{array}{l}\text { Based on Q. alba from McCormack et al. (2012), white oak with moderate } \\
\text { growth rate }\end{array}$ \\
\hline Quercus muehlenbergii & 2 & 2 & 310 & 1.03 & 1.03 & $\begin{array}{l}\text { Based on } Q . \text { alba from McCormack et al. (2012), white oak with moderate } \\
\text { growth rate }\end{array}$ \\
\hline Quercus nigra & 1 & 2 & 275 & 1.18 & 1.18 & $\begin{array}{l}\text { Based on } Q . \text { alba from McCormack et al. (2012), white oak with faster } \\
\text { growth rate }\end{array}$ \\
\hline Quercus nuttallii & 3 & 2 & 215 & 1.44 & 1.44 & $\begin{array}{l}\text { Based on } Q . \text { rubra from McCormack et al. (2012), red oak with faster } \\
\text { growth rate, species also known as } Q \text {. texana }\end{array}$ \\
\hline Quercus palustris & 2 & 2 & 215 & 1.44 & 1.44 & $\begin{array}{l}\text { Based on } Q . \text { rubra from McCormack et al. (2012), red oak with faster } \\
\text { growth rate }\end{array}$ \\
\hline Quercus phellos & 2 & 2 & 215 & 1.44 & 1.44 & $\begin{array}{l}\text { Based on } Q . \text { rubra from McCormack et al. (2012), red oak with faster } \\
\text { growth rate }\end{array}$ \\
\hline Quercus prinus & 1 & 2 & 335 & 0.92 & 0.92 & $\begin{array}{l}\text { Based on } Q . \text { alba from McCormack et al. (2012), white oak with slower } \\
\text { growth rate }\end{array}$ \\
\hline Quercus rubra & 1 & 1 & 235 & 1.35 & 1.35 & McCormack et al. (2012); McCormack et al. (Internal review) \\
\hline Quercus shumardii & 3 & 2 & 235 & 1.35 & 1.35 & $\begin{array}{l}\text { Based on Q. rubra from McCormack et al. (2012), red oak with moderate } \\
\text { growth rate }\end{array}$ \\
\hline Quercus stellata & 1 & 2 & 335 & 0.92 & 0.92 & $\begin{array}{l}\text { Based on } Q . \text { alba from McCormack et al. (2012), white oak with slower } \\
\text { growth rate }\end{array}$ \\
\hline Quercus velutina & 1 & 2 & 235 & 1.35 & 1.35 & $\begin{array}{l}\text { Based on } Q . \text { rubra from McCormack et al. (2012), red oak with moderate } \\
\text { growth rate }\end{array}$ \\
\hline Quercus virginiana & 2 & 2 & 275 & 1.18 & 1.18 & $\begin{array}{l}\text { Based on } Q . \text { alba from McCormack et al. (2012), white oak with faster } \\
\text { growth rate }\end{array}$ \\
\hline Sassafras albidum & 1 & 1 & 317 & 1.00 & 1.15 & McCormack et al. (2012); McCormack et al. (Internal review) \\
\hline Tilia americana & 2 & 2 & 230 & 1.37 & 1.37 & Based on $T$. cordata from Withington et al. (2006) \\
\hline Tsuga canadensis & 1 & 3 & 425 & 0.54 & 0.75 & Slow growth rate with moderately coarse roots \\
\hline Ulmus alata & 1 & 3 & 240 & 1.33 & 1.33 & Medium fine roots, moderate growth rate \\
\hline Ulmus americana & 2 & 3 & 210 & 1.46 & 1.46 & Medium fine roots, fast growth rate \\
\hline
\end{tabular}




\begin{tabular}{|c|c|c|c|c|c|c|}
\hline \multirow[t]{2}{*}{ Species } & \multirow{2}{*}{$C D_{i}$} & \multirow{2}{*}{$C R_{i}$} & \multirow{2}{*}{$\begin{array}{c}\text { Lifespan } \\
\text { (days), } \boldsymbol{L}_{\boldsymbol{F} S}\end{array}$} & \multicolumn{2}{|c|}{$\begin{array}{c}\text { Turnover }\left(\mathrm{yr}^{-1}\right) \\
\mathrm{T}_{F S}\end{array}$} & \multirow[t]{2}{*}{ Notes and Citations for root lifespan/turnover } \\
\hline & & & & Original & Final & \\
\hline Ulmus crassifolia & 3 & 3 & 210 & 1.46 & 1.46 & Medium fine roots, fast growth rate \\
\hline Ulmus rubra & 2 & 3 & 210 & 1.46 & 1.46 & Medium fine roots, fast growth rate \\
\hline Ulmus thomasii & 3 & 3 & 240 & 1.33 & 1.33 & Medium fine roots, moderate growth rate \\
\hline
\end{tabular}

\section{References}

Baddeley JA, Watson CA (2005) Influences of Root Diameter, Tree Age, Soil Depth and Season on Fine Root Survivorship in Prunus avium. Plant and Soil, 276, 15-22.

Coleman MD, Dickson RE, Isebrands JG (2000) Contrasting fine-root production, survival and soil $\mathrm{CO}_{2}$ efflux in pine and poplar plantations. Plant and Soil, 225, 129-139.

Crabtree RC, Bernston GM (1994) Root Architectural Responses of Betula-Lenta to Spatially Heterogeneous Ammonium and Nitrate. Plant and Soil, 158, 129-134.

Espeleta JF, West JB, Donovan LA (2009) Tree species fine-root demography parallels habitat specialization across a sandhill soil resourc gradient. Ecology, 90, 1773-1787.

Gill RA, Jackson RB (2000) Global patterns of root turnover for terrestrial ecosystems. New Phytologist, 147, 13-31.

Guo D, Mitchell RJ, Withington JM, Fan P-P, Hendricks JJ (2008) Endogenous and exogenous controls of root life span, mortality and nitrogen flux in a longleaf pine forest: root branch order predominates. Journal of Ecology, 96, 737-745.

Iversen CM, Ledford J, Norby RJ (2008) CO2 enrichment increases carbon and nitrogen input from fine roots in a deciduous forest. New Phytologist, 179, 837-847.

Kern CC, Friend AL, Johnson JMF, Coleman MD (2004) Fine root dynamics in a developing Populus deltoides plantation. Tree Physiology, 24, 651660.

King JS, Albaugh TJ, Allen HL, Buford M, Strain BR, Dougherty P (2002) Below-ground carbon in put to soil is control led by nutrient availability and fine root dynamics in loblolly pine. New Phytologist, 154, 389-398.

Mainiero R, Kazda M (2006) Depth-related fine root dynamics of Fagus sylvatica during exceptional drought. Forest Ecology and Management, 237, 135-142.

Majdi H, Kangas P (1997) Demography of fine roots in response to nutrient applications in a Norway spruce stand in southwestern Sweden. Ecoscience, 4, 199-205.

Majdi H, Pregitzer K, Moren AS, Nylund JE, Agren GI (2005) Measuring fine root turnover in forest ecosystems. Plant and Soil, 276, 1-8. 
Mccormack ML, Adams TS, Smithwick EA, Eissensat DM (2012) Predicting fine root lifespan from plant functional traits in temperate trees. New Phytologist, 195, 823-831.

Mccormack ML, Adams TS, Smithwick EA, Eissensat DM (Internal review) Fine root turnover: a story of root production and root phenology.

Peek MS, Leffler AJ, Hipps L, Ivans S, Ryel RJ, Caldwell MM (2006) Root turnover and relocation in the soil profile in response to seasonal soil water variation in a natural stand of Utah juniper (Juniperus osteosperma). Tree Physiology, 26, 1469-1476.

Persson HÅ, Stadenberg I (2009) Fine root dynamics in a Norway spruce forest (Picea abies (L.) Karst) in eastern Sweden. Plant and Soil, 330, 329344.

Pritchard SG, Strand AE, Mccormack ML et al. (2008) Fine root dynamics in a loblolly pine forest are influenced by free-air-CO2-enrichment: a sixyear-minirhizotron study. Global Change Biology, 14, 588-602.

Ruess RW, Hendrick RL, Burton AJ, Pregitzer KS, Sveinbjornsson B, Allen ME, Maurer GE (2003) Coupling fine root dynamics with ecosystem carbon cycling in black spruce forests of interior Alaska. Ecological Monographs, 73, 643-662.

Shi J, Wang Z, Yu S, Quan X, Sun Y, Jia S, Mei L (2008) Estimation of fine root production, mortality and turnover with Minirhizotron in Larix gmelinii and Fraxinus mandshurica plantations. Frontiers of Biology in China, 3, 496-506.

Strand AE, Pritchard SG, Mccormack ML, Davis MA, Oren R (2008) Irreconcilable differences: Fine-root life spans and soil carbon persistence. Science, 319, 456-458.

Symbula M, Day Jr FP (1988) Evaluation of two methods for estimating belowground production in a freshwater swamp forest. American Midland Naturalist, 405-415\%@0003-0031.

Tjoelker MG, Craine JM, Wedin D, Reich PB, Tilman D (2005) Linking leaf and root trait syndromes among 39 grassland and savannah species. New Phytologist, 167, 493-508.

Wells CE, Glenn DM, Eissenstat DM (2002) Changes in the risk of fine-root mortality with age: A case study in peach, Prunus persica (Rosaceae). American Journal of Botany, 89, 79-87.

West JB, Espeleta JF, Donovan LA (2004) Fine root production and turnover across a complex edaphic gradient of a Pinus palustris-Aristida stricta savanna ecosystem. Forest Ecology and Management, 189, 397-406.

Wiseman PE, Wells CE (2009) Arbuscular mycorrhizal inoculation affects root development of Acer and Magnolia species. Journal of Environmental Horticulture, 27, 70-79 \%@ 0738-2898.

Withington JM, Reich PB, Oleksyn J, Eissenstat DM (2006) Comparisons of structure and life span in roots and leaves among temperate trees. Ecological Monographs, 76, 381-397.

Xia M, Guo D, Pregitzer KS (2010) Ephemeral root modules in Fraxinus mandshurica. New Phytol, 188, 1065-1074.

Yanai RD, Fisk MC, Fahey TJ, Cleavitt NL, Park BB (2008) Identifying roots of northern hardwood species: patterns with diameter and depth. Canadian Journal of Forest Research-Revue Canadienne De Recherche Forestiere, 38, 2862-2869.

Yu SQ, Wang ZQ, Shi JW, Yu LZ, Quan XK (2009) Effects of nitrogen fertilization on fine root lifespan of Fraxinus mandshurica and Larix gmelinii. Ying Yong Sheng Tai Xue Bao, 20, 2332-2338.

Zanne AE, Lopez-Gonzalez G, Coomes DA et al. (2009) Global wood density database, Dryad. pp Page, www.datadryad.org. 
Zeleznik JD, Dickmann DI (2004) Effects of high temperatures on fine roots of mature red pine (Pinus resinosa) trees. Forest Ecology and Management, 199, 395-409. 